\title{
A model study of the coupled biological and physical dynamics in Lake Michigan
}

\author{
Changsheng Chen ${ }^{\mathrm{a}, *}$, Rubao Ji ${ }^{\mathrm{d}}$, David J. Schwab ${ }^{\mathrm{b}}$, Dmitry Beletsky ${ }^{\mathrm{b}}$,

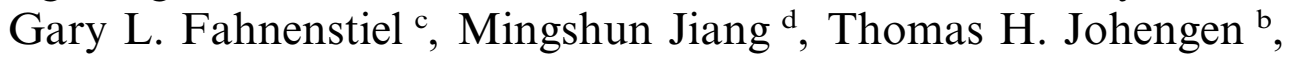 \\ Henry Vanderploeg ${ }^{\mathrm{b}}$, Brian Eadie ${ }^{\mathrm{b}}$, Judith Wells Budd ${ }^{\mathrm{e}}$, Marie H. Bundy ${ }^{\mathrm{f}}$, \\ Wayne Gardner ${ }^{\mathrm{g}}$, James Cotner ${ }^{\mathrm{h}}$, Peter J. Lavrentyev ${ }^{\mathrm{i}}$ \\ a School for Marine Science and Technology, University of Massachusetts-Dartmouth, 706 South Rodney French Boulevard, \\ New Bedford, MA 02744-1221, USA \\ b NOAA/GLERL, 2205 Commonwealth Boulevard, Ann Arbor, MI 48105-2945, USA \\ c The Lake Michigan Field Station, NOAA/GLERL, 1431 Beach Street, Muskegon, MI 49441, USA \\ ${ }^{\mathrm{d}}$ Department of Marine Sciences, The University of Georgia, Athens, GA 30602, USA \\ e Department of Geological Engineering and Sciences, Michigan Technological University, Houghton, MI 49931, USA \\ ${ }^{\mathrm{f}}$ Academy of Natural Sciences, Estuarine Research Center, St. Leonard, MD 20005, USA \\ g Department of Marine Sciences, University of Texas at Austin, Austin, TX 78712, USA \\ ${ }^{\mathrm{h}}$ Department of Ecology Evolution and Behavior, University of Minnesota, St. Paul, MN 55108, USA \\ i Department of Biology, University of Akron, Akron, OH 44325, USA
}

Received 24 January 2001; received in revised form 22 October 2001; accepted 31 October 2001

\begin{abstract}
A coupled physical and biological model was developed for Lake Michigan. The physical model was the Princeton ocean model (POM) driven directly by observed winds and net surface heat flux. The biological model was an eight-component, phosphorus-limited, lower trophic level food web model, which included phosphate and silicate for nutrients, diatoms and non-diatoms for dominant phytoplankton species, copepods and protozoa for dominant zooplankton species, bacteria and detritus. Driven by observed meteorological forcings, a 1-D modeling experiment showed a controlling of physical processes on the seasonal variation of biological variables in Lake Michigan: diatoms grew significantly in the subsurface region in early summer as stratification developed and then decayed rapidly in the surface mixed layer when silicate supplied from the deep stratified region was reduced as a result of the formation of the thermocline. The non-diatoms subsequently grew in mid and late summer under a limited-phosphate environment and then declined in the fall and winter as a result of the nutrient consumption in the upper eutrophic layer, limitation of nutrients supplied from the deep region and meteorological cooling and wind mixing. The flux estimates suggested that the microbial loop had a significant contribution in the growth of microzooplankton and hence, to the lower-trophic level food web system. The model results agreed with observations, suggesting that the
\end{abstract}

* Corresponding author. Tel.: + 1-508-910-6388; fax: + 1-508-910-6371.

E-mail address: c1chen@umassd.edu (C. Chen). 
model was robust to capture the basic seasonal variation of the ecosystem in Lake Michigan. (C) 2002 Published by Elsevier Science B.V.

Keywords: Ecosystem; Coupled biological and physical model; Phytoplankton growth; Microbial processes; Lake Michigan

\section{Introduction}

Lake Michigan is characterized as a typical phosphorus-limited lake ecosystem (Eadie et al., 1984; McCormick and Tarapchak, 1984; Schelske et al., 1986). Previous biological and chemical observations showed that the annual averaged concentrations of total inorganic nitrogen and phosphate in the lake have been increasing dramatically (Brooks and Edington, 1994). Nitrogen, a requisite component for the growth of phytoplankton in the coastal ocean, is not a limiting factor in Lake Michigan (Neilson et al., 1994). The phosphorus in Lake Michigan is supplied and maintained mainly through four processes: (1) external loading; (2) internal recycling; (3) sediment flux; and (4) nutrient release of suspended sediments. Recent measurements reveal a net increase of the total phosphorus during the spring phytoplankton bloom. Of this increment, $20 \%$ is accounted for by the external phosphorus loading (Brooks and Edington, 1994) and only $4 \%$ is supplied from the bottom sediment flux (Conley et al., 1988). Although the previous interpretation of phosphorus loading and flux is somewhat in question, there is no doubt that a large portion of the net increase of phosphorus is due to the nutrient releases from suspended sediment and internal recycling (Eadie et al., 1984; Johengen et al., 1994).

Silicon also plays an important role in regulating planktonic communities in Lake Michigan. The collapse of the spring diatom bloom in southern Lake Michigan generally occurs in summer as silicon is rapidly depleted in the euphotic zone due to the restriction of nutrient supplies from the deep region below the thermocline (Scavia and Fahnenstiel, 1987). Unlike phosphorus, the silicon in the water column is hardly released from the detrital pool and only $21 \%$ of it is accounted for by the sediment flux at the bottom (Conley et al., 1988).
In early spring, the planktonic community in Lake Michigan is dominated by diatoms. In general, there are two types of abundant diatoms in the lake: large net ones (Melosira, Asterionella, etc.) and small centrics $(5-10 \mu \mathrm{m})$. When the wind mixing-induced thermocline is established, it acts like a barrier to restrict the silicon flux from the deep water. As a result, the biomass of diatoms decreases dramatically in late spring as the silicon in the photic zone is depleted (Scavia and Fahnenstiel, 1987). The non-diatoms, which comprise of large flagellates (Cryptophytes) and a bunch of small flagellates $(3-10 \mu \mathrm{m}$, Chrysophytes, Haptophytes and some Prasinophytes, etc.), grow up gradually under conditions of limited phosphorus in late spring through summer (Sherr et al., 1988). Therefore, because of the silicon limitation, the growth of phytoplankton in Lake Michigan features two distinct patterns: the diatom bloom in early spring and then non-diatoms in late spring through summer.

The major consumers of phytoplankton in Lake Michigan are large zooplankton (copepods) and microzooplankton (Ciliates, Daphnia spp. and Calanoida, etc.). A high abundance of copepods occurs in early spring, which is consistent with a rapid growth of diatoms as stratification develops. The dominant species shift to the microzooplankton as diatoms are depleted and non-diatoms grow up. The microbial food web (MFW) is believed to be a major contributor to the abundance of microzooplankton in Great Lakes (Gardner et al., 1986; Carrick and Fahnenstiel, 1990; Carrick et al., 1991; Valiela, 1995). This is evident from the recent observation that the heterotrophic bacteria can account for $\approx 22 \%$ of the total plankton biomass and heterotrophic protozoa (a major component of the MFW) can account for $\approx 32 \%$ of the total heterotrophic micro-organisms in St. Lawrence Great Lakes (Fahnenstiel et al., 1998). Protozoan ciliates constituted $\approx 30 \%$ of the zooplankton biomass in the southern part of the lake in a 1-year survey 
conducted from December 1986 to November 1987 (Carrick and Fahnenstiel, 1990).

Previous observations and laboratory experiments have shown a clear schematic of the lower trophic level food web of Lake Michigan, which provide a foundation for modeling exploration. Based on biological measurements, Scavia (1979, 1980) developed a food web model for Lake Ontario. The model was driven by observed biological distributions with inclusion of a specified one-dimensional (1-D) temperature profile and empirically determined vertical diffusion. This model was modified and applied to Lake Michigan (Scavia et al., 1988). The updated version of the biological food web model consisted of three phytoplankton components (diatoms, flagellates and blue greens), two nutrients (silicon and phosphorus) and two crustaceans (Diaptomu and Daphnia). Numerical experiments based on this biological model revealed the basic characteristics of the transformation and fluxes between nutrients, phytoplankton and zooplankton in Great Lakes ecosystems. A similar model was also developed for Saginaw Bay, Lake Huron by Bieman and Dolan (1981). All these biological models were driven by idealized simple physical fields, which could not resolve the 3-D or even 2-D time and spatial distributions of biological fields in Great Lakes.

There has not been a lower trophic level food web model available for Lake Michigan until our present modeling studies. Although previous observations have provided us with some insights into the structure of the biological community in Lake Michigan, the impact of the physical processes on the seasonal variation of the food web system has not been well examined. How do stratification and wind mixing control the seasonal variation and species regulation of the plankton in Lake Michigan? What is the role of microbial food web in the ecosystem energy balance in Lake Michigan under a realistic physical condition? Could we develop a fully coupled physical and biological model to simulate the seasonal variation of the ecosystem in this lake?

As one component of the modeling projects of the Episodic Events Great Lake Experiments (EEGLE), a fully coupled physical and biological model was developed for Lake Michigan. The physical part was the well-calibrated Lake Michigan circulation model that was originally modified from the Princeton ocean model (POM) by the NOAA Great Lake Laboratory modeling group (Beletsky and Schwab, 1998; Beletsky et al., 2000; Schwab et al., 2000). The biological part consisted of an eight-component, phosphorus-controlled, lower trophic level food web model with inclusion of phosphate and silicate for nutrients, diatoms and non-diatoms for dominant phytoplankton species, copepod and heterotrophic flagellate for dominant zooplankton species, bacteria and detritus. This coupled model has been tested and calibrated under the realistic lake environment of 1994-1995 and a spring plume event of 1998.

The objectives of this paper are (1) to describe in detail the development of this coupled model; and (2) to use this model to examine the impact of physical processes on the seasonal variation of the plankton and the interaction between biological variables in a food web system in this lake. Modeling studies were focused on a 1-D numerical simulation of the plankton at a long-term monitoring station (shown in Fig. 1) for 1994-1995. A 3-D experiment, with focus of the impact of seasonally recurring coastal suspended sediment plume on the spatial distribution of the plankton in southern Lake Michigan, is presented in a separate paper in this volume (Ji et al., 2002).

The remaining sections are organized as follows. The coupled biological and physical model and the design of numerical experiments are described in Section 2. The model results of the 1-D experiments are presented in Section 3. The impacts of physical and microbial processes on the food web are examined in Section 4. The sensitivity analysis of biological parameters is given in Section 5 and finally, conclusions are summarized in Appendix B.

\section{The coupled biological and physical model}

\subsection{Biological model}

The biological model is based on the observed features of the lower trophic level food web in 
Lake Michigan (Scavia and Fahnenstiel, 1987). It is a phosphorus-controlled model with eight independent variables (Fig. 2). The governing equations are given as:

$\frac{d P_{\mathrm{L}}}{d t}-\frac{\partial}{\partial z}\left(A_{\mathrm{h}} \frac{\partial P_{\mathrm{L}}}{\partial z}\right)$

$=\mathrm{L} P($ uptake $)-\mathrm{L} P($ mortality $)-\mathrm{L} Z \mathrm{~L} P($ grazing $)$

$-\mathrm{L} P($ sinking$)$

$\frac{d P_{\mathrm{S}}}{d t}-\frac{\partial}{\partial z}\left(A_{\mathrm{h}} \frac{\partial P_{\mathrm{S}}}{\partial z}\right)$

$=\mathrm{S} P($ uptake $)-\mathrm{S} P($ mortality $)-\mathrm{S} Z \mathrm{~S} P($ grazing $)$

$\frac{d Z_{\mathrm{L}}}{d t}-\frac{\partial}{\partial z}\left(A_{\mathrm{h}} \frac{\partial Z_{\mathrm{L}}}{\partial z}\right)$

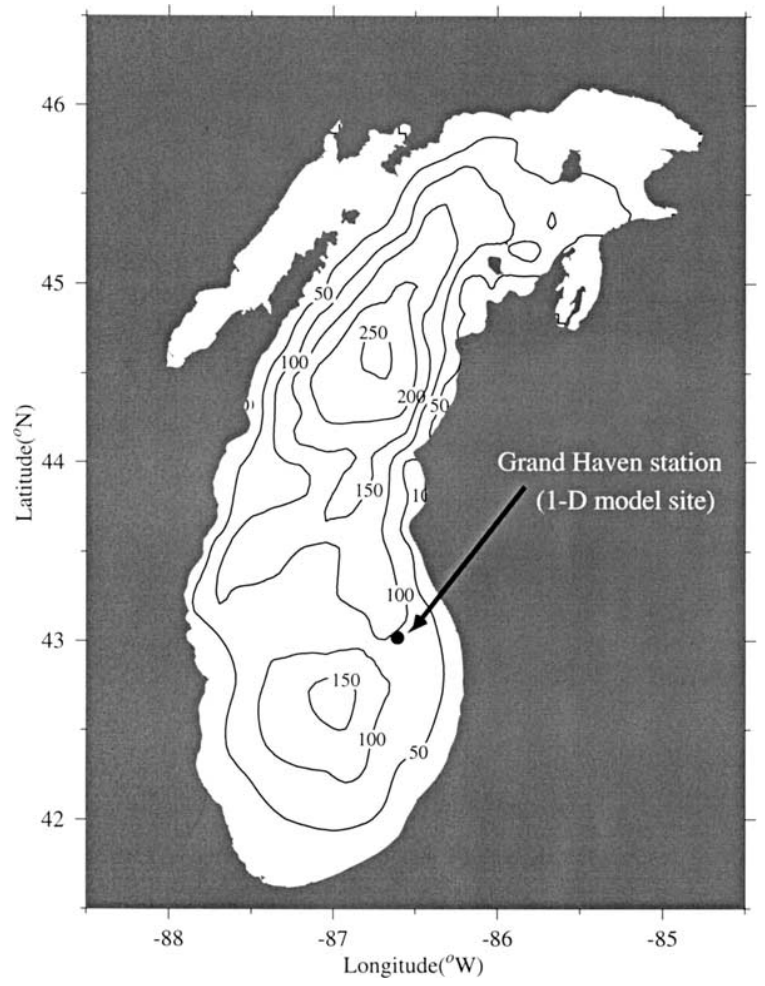

Fig. 1. Bathmetry of Lake Michigan and the location of the Grand Haven monitoring station chosen for the 1-D model experiment. The contour of the water depth was plotted with an interval of $50 \mathrm{~m}$.

$$
\begin{aligned}
= & \varepsilon^{Z_{\mathrm{L}}} \sigma_{\mathrm{P}} \mathrm{L} Z \mathrm{~L} P(\text { grazing })+\varepsilon^{Z_{\mathrm{LS}}} \mathrm{L} Z \mathrm{~S} Z \text { (grazing) } \\
& -\mathrm{L} Z \text { (mortality) }
\end{aligned}
$$

$$
\begin{aligned}
& \frac{d Z_{\mathrm{S}}}{d t}-\frac{\partial}{\partial z}\left(A_{\mathrm{h}} \frac{\partial Z_{\mathrm{S}}}{\partial z}\right) \\
& =\varepsilon^{Z_{\mathrm{S}} \mathrm{S} Z \mathrm{~S} P(\text { grazing})-\mathrm{L} Z \mathrm{~S} Z \text { (grazing) }} \\
& \quad+\varepsilon^{B} \mathrm{~S} Z B(\text { grazing })-\mathrm{S} Z \text { (mortality) }
\end{aligned}
$$

$\frac{d B}{d t}-\frac{\partial}{\partial z}\left(A_{\mathrm{h}} \frac{\partial B}{\partial z}\right)$

$=D B($ decomposition $)+B P($ uptake $)$

$$
\text { - } \mathrm{S} Z B \text { (grazing) - B(mortality) }
$$

$$
\begin{aligned}
& \frac{d D_{\mathrm{P}}}{d t}-\frac{\partial}{\partial z}\left(A_{\mathrm{h}} \frac{\partial D_{\mathrm{P}}}{\partial z}\right) \\
& =\left(1-\varepsilon^{z_{\mathrm{L}}}\right) \sigma_{\mathrm{P}} \mathrm{L} Z \mathrm{~L} P(\text { grazing }) \\
& +\left(1-\varepsilon^{Z_{\mathrm{s}}}\right) \mathrm{S} Z \mathrm{~S} P \text { (grazing) } \\
& +\left(1-\varepsilon^{B}\right) \mathrm{S} Z B \text { (grazing) } \\
& +\left(1-\varepsilon^{Z_{\mathrm{LS}}}\right) \mathrm{L} Z \mathrm{~S} Z \text { (grazing) } \\
& \text { - } D B \text { (decomposition) - DP(sinking) } \\
& -D P(\text { remineralization })+\sigma_{\mathrm{P}} \mathrm{L} P(\text { mortality }) \\
& +\mathrm{S} P(\text { mortality })+\mathrm{L} Z \text { (mortality) } \\
& +\mathrm{S} Z \text { (mortality) }+B \text { (mortality) }
\end{aligned}
$$

$\frac{d D_{\mathrm{S}}}{d t}-\frac{\partial}{\partial z}\left(A_{\mathrm{h}} \frac{\partial D_{\mathrm{P}}}{\partial z}\right)$

$=\sigma_{\mathrm{S}} \mathrm{L} Z \mathrm{~L} P($ grazing $)+\sigma_{\mathrm{S}} \mathrm{L} P($ mortality $)$

- $D \mathrm{~S}$ (remineralization)

$$
\begin{aligned}
\frac{d P}{d t} & -\frac{\partial}{\partial z}\left(A_{\mathrm{h}} \frac{\partial P}{\partial z}\right) \\
= & -\sigma_{\mathrm{P}} \mathrm{L} P(\text { uptake })-\mathrm{S} P(\text { uptake })-B P(\text { uptake }) \\
& +D P(\text { remineralization })+P Q
\end{aligned}
$$

$$
\begin{aligned}
& \frac{d S_{i}}{d t}-\frac{\partial}{\partial z}\left(A_{\mathrm{h}} \frac{\partial S_{i}}{\partial z}\right) \\
& =-\sigma_{\mathrm{S}} \mathrm{L} P(\text { uptake })+D \mathrm{~S}(\text { remineralization })+\mathrm{S} Q
\end{aligned}
$$




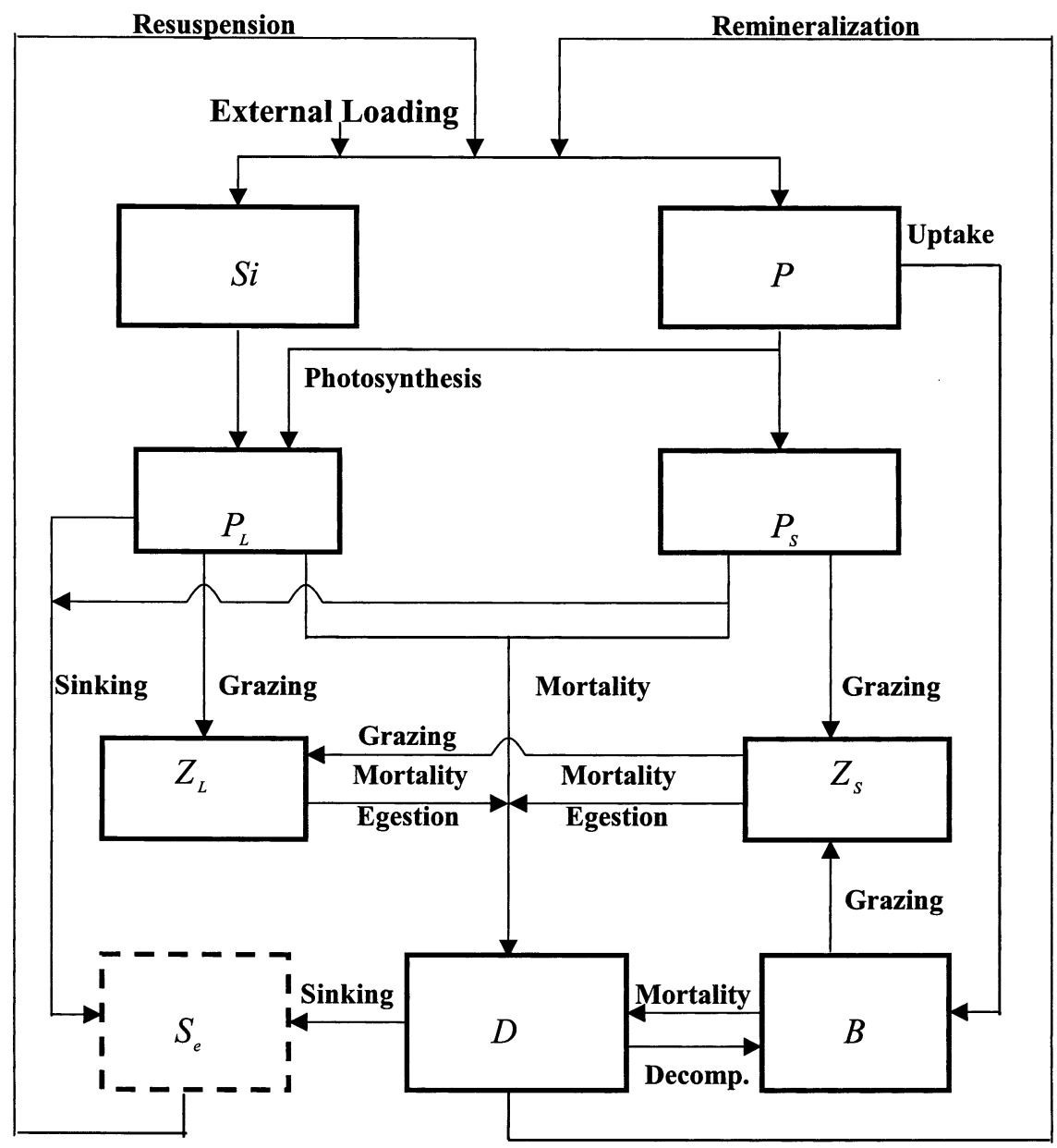

Fig. 2. Schematic of the lower trophic level food web model in Lake Michigan. The definition for each symbol is given in the text.

where $P_{\mathrm{L}}, P_{\mathrm{S}}, Z_{\mathrm{L}}, Z_{\mathrm{S}}, B, P$ and $S_{i}$ are the large size phytoplankton, small size phytoplankton, large size zooplankton, small size zooplankton, bacteria, phosphorus, and silicon, respectively. $D_{\mathrm{P}}$ and $D_{\mathrm{S}}$ are the phosphate- and silica-related components of detritus. $A_{\mathrm{h}}$ is the thermal diffusion coefficient that is calculated using the Mellor and Yamada level 2.5 turbulent closure scheme incorporated in the physical model.

$\frac{d}{d t}=\frac{\partial}{\partial t}+u \frac{\partial}{\partial x}+v \frac{\partial}{\partial y}+w \frac{\partial}{\partial z}$

is the derivative operator; $x, y$ and $z$ are the eastward, northward, and vertical axes of the Cartesian coordinate, and $u, v$ and $w$ are the $x, y$ and $z$ components of the velocity. The definition of parameters $\varepsilon^{Z_{\mathrm{L}}}, \varepsilon^{Z_{\mathrm{LS}}}, \varepsilon^{Z_{\mathrm{S}}}, \varepsilon^{B}, \sigma_{\mathrm{S}}$ and $\sigma_{\mathrm{P}}$ are given in Table 1. $P Q$ and $S Q$ are the phosphorus and silicon fluxes from suspended sediments. The mathematical formula of $\mathrm{L} P$ (uptake), $\mathrm{L} Z \mathrm{~L} P$ (grazing), $\mathrm{S} P$ (uptake), $\mathrm{S} Z \mathrm{~S} P$ (grazing), $\mathrm{L} Z \mathrm{~S} Z$ (grazing), $\mathrm{S} Z B$ (grazing), $D B$ (decomposition), $B P$ (uptake), $D P$ (remineralization), $D \mathrm{~S}$ (remineralization), LP (sinking), $D P$ (sinking), LP (mortality), $\mathrm{S} P$ (mortality), $\mathrm{L} Z$ (mortality), $\mathrm{S} Z$ (mortality) and $B$ (mortality) are given in detail in Appendix A.

In the model, phosphorus and silicon are two limiting nutrients that control the primary production. Nitrogen is not included in the model 
Table 1

Bio-parameters

\begin{tabular}{|c|c|c|c|c|}
\hline Parameter & Definition & Value used & Ranges & Sources \\
\hline$V_{\max }^{P_{\mathrm{L}}}$ & Maximum growth rate for $P_{\mathrm{L}}$ & $1.6 \mathrm{~d}^{-1}$ & $0.8-6 \mathrm{~d}^{-1}$ & $\begin{array}{l}\text { (Bieman and Dolan, 1981; Scavia et } \\
\text { al., 1988) }\end{array}$ \\
\hline$V_{\max }^{P \mathrm{~s}}$ & Maximum growth rate for $P_{\mathrm{S}}$ & $1.2 \mathrm{~d}^{-1}$ & $0.8-2 \mathrm{~d}^{-1}$ & $\begin{array}{l}\text { (Bieman and Dolan, 1981; Scavia et } \\
\text { al., 1988) }\end{array}$ \\
\hline$V_{\max }^{S}$ & Maximum Si uptake rate by $P_{\mathrm{L}}$ & $1.2 \mathrm{~d}^{-1}$ & $0.8-6 \mathrm{~d}^{-1}$ & Various sources \\
\hline$V_{\max }^{B}$ & Maximum $P$ uptake rate by $B$ & $0.05 \mathrm{~d}^{-1}$ & $?$ & \\
\hline$V_{\max }^{\mathrm{DOP}}$ & Maximum DOP uptake rate by $B$ & $5 d^{-1}$ & $23-144 d^{-1}$ & (Bentzen et al., 1992) \\
\hline$k_{P_{\mathrm{L}}}$ & $\begin{array}{l}\text { Half-saturation constant for the } P \\
\text { uptake by } P_{\mathrm{L}}\end{array}$ & $0.2 \mu \mathrm{mol} P 1^{-1}$ & $\begin{array}{l}0.07-0.4 \mu \mathrm{mol} P \\
1^{-1}\end{array}$ & $\begin{array}{l}\text { (Bieman and Dolan, 1981; Tilman et } \\
\text { al., 1982) }\end{array}$ \\
\hline$k_{P_{\mathrm{S}}}$ & $\begin{array}{l}\text { Half-saturation constant for the } P \\
\text { uptake by } P_{\mathrm{S}}\end{array}$ & $\begin{array}{c}0.05 \mu \mathrm{mol} P \\
1^{-1}\end{array}$ & $\begin{array}{l}0.015-? \mu \mathrm{mol} P \\
1^{-1}\end{array}$ & (Bieman and Dolan, 1981) \\
\hline$k_{\mathrm{S}}$ & $\begin{array}{l}\text { Half-saturation constant the } \mathrm{Si} \\
\text { uptake by } P_{\mathrm{L}}\end{array}$ & $1_{1^{-1}}^{5.0 \mu \mathrm{mol} \mathrm{Si}}$ & $\begin{array}{l}3.5-3.57 \mu \mathrm{mol} \\
\text { Si } 1^{-1}\end{array}$ & $\begin{array}{l}\text { (Bieman and Dolan, 1981; Jorgensen } \\
\text { et al., 1991) }\end{array}$ \\
\hline$k_{B}$ & $\begin{array}{l}\text { Half-saturation constant for the } P \\
\text { uptake by } B\end{array}$ & $0.2 \mu \mathrm{mol} P 1^{-1}$ & $\begin{array}{c}0.02-0.2 \mu \mathrm{mol} P \\
1^{-1}\end{array}$ & (Cotner and Wetzel, 1992) \\
\hline$k_{\mathrm{DOP}}$ & $\begin{array}{l}\text { Half-saturation constant for the } \\
\text { DOP uptake by } B\end{array}$ & $0.1 \mu \mathrm{mol} P 1^{-1}$ & $\begin{array}{l}0.005-0.02 \mu \mathrm{mol} \\
P 1^{-1}\end{array}$ & (Bentzen et al., 1992) \\
\hline$G_{\max }^{Z_{\mathrm{L}}}$ & Maximum $P_{\mathrm{L}}$ grazing rate by $Z_{\mathrm{L}}$ & $0.4 \mathrm{~d}^{-1}$ & $0.2-0.86 \mathrm{~d}^{-1}$ & $\begin{array}{l}\text { (Scavia et al., 1988; Jorgensen et al., } \\
\text { 1991) }\end{array}$ \\
\hline$G_{\max }^{Z \mathrm{~s}}$ & Maximum $P_{\mathrm{S}}$ grazing rate by $Z_{\mathrm{S}}$ & $0.2 \mathrm{~d}^{-1}$ & $0.1 \mathrm{~d}^{-1}$ & (Bieman and Dolan, 1981) \\
\hline$G_{\max }^{B}$ & Maximum $B$ grazing rate by $Z_{\mathrm{S}}$ & $3.5 \mathrm{~d}^{-1}$ & $3.5 \mathrm{~d}^{-1}$ & (Hamilton and Preslon, 1970) \\
\hline$G_{\max }^{Z_{\mathrm{LS}}}$ & Maximum $Z_{\mathrm{S}}$ grazing rate by $Z_{\mathrm{L}}$ & $0.4 \mathrm{~d}^{-1}$ & $?$ & \\
\hline$k^{Z_{\mathrm{L}}}$ & Ivlev constant for $Z_{\mathrm{L}}$ grazing & $0.061 \mu \mathrm{mol}^{-1}$ & $0.001-11 \mu \mathrm{mol}^{-1}$ & $\begin{array}{l}\text { (Scavia et al., 1988; Jorgensen et al., } \\
\text { 1991) }\end{array}$ \\
\hline$k^{Z_{\mathrm{S}}}$ & Ivlev constant for $P_{\mathrm{s}}$ grazing by $Z_{\mathrm{s}}$ & $0.021 \mu \mathrm{mol}^{-1}$ & $\begin{array}{c}0.0111 \\
\mathrm{~mol}^{-1}\end{array}$ & (Bieman and Dolan, 1981) \\
\hline$k^{B}$ & $\begin{array}{l}\text { Ivlev constant for the } B \text { grazing by } \\
Z_{\mathrm{s}}\end{array}$ & $0.031 \mu \mathrm{mol}^{-1}$ & $\begin{array}{c}0.0221 \\
\mu \mathrm{mol}^{-1}\end{array}$ & (Hamilton and Preslon, 1970) \\
\hline$k^{Z_{\mathrm{LS}}}$ & $\begin{array}{l}\text { Ivlev constant for the } Z_{\mathrm{s}} \text { grazing by } \\
Z_{\mathrm{L}}\end{array}$ & 0.07 & $?$ & \\
\hline$\varepsilon^{Z_{\mathrm{L}}}$ & Assimilation efficiency of $Z_{\mathrm{L}}$ & 0.35 & $0.15-0.5$ & (Jorgensen et al., 1991) \\
\hline$\varepsilon^{Z \mathrm{~s}}$ & Assimilation efficiency of $Z_{\mathrm{s}}$ & 0.3 & $?$ & \\
\hline$\varepsilon^{B}$ & $\begin{array}{l}\text { Assimilation efficiency of } B \text { grazing } \\
\text { by } Z_{\mathrm{s}}\end{array}$ & 0.3 & $?$ & \\
\hline$\varepsilon^{Z_{\mathrm{LS}}}$ & $\begin{array}{l}\text { Assimilation efficiency of the } Z_{\mathrm{s}} \text { by } \\
Z_{\mathrm{L}}\end{array}$ & 0.6 & $?$ & \\
\hline$\alpha^{Z_{\mathrm{L}}}$ & Mortality rate of $Z_{\mathrm{L}}$ & $0.02 \mathrm{~d}^{-1}$ & $0.01-0.05 \mathrm{~d}^{-1}$ & $\begin{array}{l}\text { (Bieman and Dolan, 1981; Jorgensen } \\
\text { et al., 1991) }\end{array}$ \\
\hline$\alpha^{Z \mathrm{~s}}$ & Mortality rate of $Z_{\mathrm{s}}$ & $0.03 \mathrm{~d}^{-1}$ & $0.1 \mathrm{~d}^{-1}$ & (Bieman and Dolan, 1981) \\
\hline$\alpha^{B}$ & Mortality rate of $B$ & $0.5 \mathrm{~d}^{-1}$ & $0.5-5.9 \mathrm{~d}^{-1}$ & (Jorgensen et al., 1991) \\
\hline$k_{0}$ & $\begin{array}{l}\text { Photosynthetic attenuation } \\
\text { coefficient }\end{array}$ & $0.08 \mathrm{~m}^{-1}$ & $0.12-0.17 \mathrm{~m}^{-1}$ & (Scavia et al., 1986) \\
\hline$\mu_{\mathrm{D}}$ & $\begin{array}{l}\text { Proportionality of DOP from the } \\
\text { detrital } P\end{array}$ & 0.02 & $0.1-0.58$ & (Valiela, 1995) \\
\hline$\delta_{P_{\mathrm{L}}}$ & Sinking velocity of $P_{\mathrm{L}}$ & $0.6 \mathrm{~m} \mathrm{~d}^{-1}$ & $0.5-9 \mathrm{~m} \mathrm{~d}^{-1}$ & $\begin{array}{l}\text { (Scavia et al., 1988; Jorgensen et al., } \\
\text { 1991) }\end{array}$ \\
\hline$\delta_{P_{\mathrm{S}}}$ & Sinking velocity of $P_{\mathrm{s}}$ & $0.3 \mathrm{~m} \mathrm{~d}^{-1}$ & $0.01-3 \mathrm{~m} \mathrm{~d}^{-1}$ & (Fahnenstiel and Scavia, 1987b) \\
\hline$\delta_{\mathrm{D}}^{\mathrm{s}}$ & Sinking velocity of $D$ & $0.6 \mathrm{~m} \mathrm{~d}^{-1}$ & $0.5-1 \mathrm{~m} \mathrm{~d}^{-1}$ & (Jorgensen et al., 1991) \\
\hline$e_{P}$ & Remineralization rate of detrital $P$ & $0.15 \mathrm{~d}^{-1}$ & $0.05 \mathrm{~d}^{-1}$ & (Fasham et al., 1990) \\
\hline$e_{\mathrm{S}}$ & Remineralization rate of detrital $\mathrm{Si}$ & $0.03 \mathrm{~d}^{-1}$ & $?$ & \\
\hline$\alpha$ & Temperature dependence coefficient & 0.069 & 0.069 & (Parsons et al., 1984) \\
\hline$\lambda_{C: C h l_{i}}$ & Ratio of carbon $(C)$ to chlorophyll & 35 & $23-79$ & (Parsons et al., 1984) \\
\hline$\lambda_{C: P}$ & Ratio of $C$ to $P$ & 80 & $?$ & (Parsons et al., 1984) \\
\hline
\end{tabular}


since it is always in sufficient supply. This food web model has the advantage of avoiding the complex ammonia dynamics (Fasham et al., 1990).

Two sizes of phytoplankton are considered in the model. One is diatom (range: $13-312 \mu \mathrm{m}$ ) and the other is small non-diatom (flagellates with a size smaller than $10 \mu \mathrm{m}$ ). In Lake Michigan, the phytoplankton is dominated by the large net diatom in early spring and is then followed by the growth of phytoflagellates and cyanobacteria or green alge (Fahnenstiel and Scavia, 1987b) in summer and autumn. The existence of these two distinct phase patterns is associated with the seasonal variation in silicon levels, which decreases rapidly as the thermocline develops. Dividing the phytoplankton species into two size groups is based on the purpose of capturing the basic seasonal pattern of the phytoplankton with the simplest food web model.

In Lake Michigan, zooplankton is dominated by copepods and cladocera all year around (Scavia and Fahnenstiel, 1987). The abundant species for copepods are Diaptomus spp. and for cladocera is Daphnia galeata mendota. Microzooplankton are dominated by ciliates and heteroflagellates. The ciliates contribute to the heterotrophic plankton and their abundant species vary significantly with seasons (Carrick and Fahnenstiel, 1990), while the heteroflagellates generally account for a small fraction of microzooplankton abundance in the lake. Based on the grazing characteristics of different sizes of zooplankton, we group the zooplankton into two categories: large and small zooplankton. The large zooplankton represents copepod and cladocera and small zooplankton includes microzooplankton.

The most preferable food for copepods in Lake Michigan is ciliates other than diatoms (Vanderploeg et al., 1988; Vanderploeg, 1994). Based on size and shape selectivity, the freshwater plankton with a size range of $3-30 \mu \mathrm{m}$ (the size of most ciliates) is preferred by calanoid copepods (Vanderploeg, 1981) and filter-feeding cladocera (Gliwicz, 1980). The linkage between copepods and ciliates in the lake is taken into account in the model by adding the grazing process of large zooplankton over small zooplankton. We also assume that copepods do not digest the diatom frustuler and thus, the silica parts of diatoms are directly deposited into detrital pool (Scavia et al. 1988). In some previous modeling studies for the reservoirs, diatoms are allowed to grow without inclusion of zooplankton grazing (Thebault and Salencon, 1993; Salencon and Thebault, 1996). Our experiments suggest that this assumption probably fails to simulate the collapse of diatoms in late autumn and caused the earlier occurrence of the diatoms' bloom in the subsequent year in Lake Michigan.

Bacteria contribute to the lower trophic level food web mainly through uptake of nutrients, decomposition of detritus and grazing by microzooplankton (Gardner et al. 1986). The mortality of bacteria directly deposits into the detritus pool, which indirectly influences the detritus remineralization to dissolved nutrients and decomposition back to bacteria. Following the procedure of Fasham et al. (1990), the total amount of bacteria is included in the model, with no separation of the attached bacteria from free bacteria.

Detritus refers to fecal pellets, dead phytoplankton, zooplankton and bacteria. In Lake Michigan, the large egestion of zooplankton and low assimilation efficiency contribute to the amount of detritus, especially in summer after stratification develops (Scavia and Fahnenstiel, 1987). The sediment flux from the bottom decreases by a factor of 10 from early spring to late summer after the thermocline is established (Eadie et al., 1984). This change accounts for part of the algal losses in Lake Michigan during summer. Since the POC remains almost unchanged in the lake in early spring through summer, the sedimentation during that period is dominated by detrital losses. This pattern is evident from previous observations, which show that after the spring bloom, the net decrease of total phosphorus is proportional in the epillimnion to sedimentation fluxes that are attributable to detritus (Brooks and Edington, 1994).

In our model, the remineralization, decomposition and sinking of detritus are taken into account in the food web system. It is difficult to resolve 
ratio of silicon to phosphorus from the total concentration of detritus, since this ratio varies with multiple factors related to the mortality of phytoplankton, zooplankton and bacteria and assimilation rate of zooplankton. For example, the growth of large phytoplankton is limited by both phosphorus and silicon, while only phosphorus is needed for small phytoplankton (non-diatoms). As a result, the dead diatoms contain both phosphorus and silicon, but dead small phytoplankton has only phosphorus. Similar processes occur for the grazing of large and small zooplankton, in which the unassimilated part of large zooplankton contributes to both phosphorus and silicon pools, but that of the small zooplankton contributes to phosphorus only. Because the ratio of phosphorus to silicon in the total detritus depends on multiple time-dependent factors, it is almost impossible to derive a simple mathematical formula to separate one from another if only total concentration of detritus is calculated. For this reason, we technically divide detritus into two components: $D_{\mathrm{P}}$ and $D_{\mathrm{S}}$, with $D_{\mathrm{P}}$ including all phosphorus-related detritus and $D_{\mathrm{S}}$ all silica-related detritus. This separation is only valid with an assumption that ratios of phosphorus to silicon in large phytoplankton and zooplankton are well-defined.

The effects of upper trophic level predators, such as large fishes, human fishing and birds, are not included in the present model. As Valiela (1995) suggested, most of these higher trophic level effects can be simulated by adding an additional sinking rate of the detrital pool. Since our interests are in the physical and biological interaction on the lower trophic food web in the lake, we neglect these higher trophic level terms based on an assumption that they have only a secondary contribution to the food web system in Lake Michigan.

The model includes 37 biological parameters. These parameters are selected according to previous observations and literature values (see Table 1). Since these parameters vary over a wide range in time and space, we first ran the model with an initial setup of parameters and then carried out a sensitivity analysis over the given parameter ranges. A detailed description of our initial setup of biological parameters is given in Appendix A.

\subsection{Physical model}

The physical model used in this study is the Princeton ocean model (POM) developed originally by Blumberg and Mellor (1987). The model incorporates the Mellor and Yamada (1982) level 2.5 turbulent closure scheme, with a modification by Galperin et al. (1988) to provide a time- and space-dependent parameterization of vertical turbulent mixing (MY2.5). The estimation of surface mixing length scale is improved by linking it with mixing intensity and the first model layer thickness (Melsom, 1996). This improvement provides a more realistic surface mixing which is critically important for simulating the thermocline and hence for nutrient supply and phytoplankton growth. The POM has been widely used in the coastal ocean and Great Lake studies.

The POM has been configured for Lake Michigan geometry (Beletsky and Schwab, 1998; Beletsky et al. 2000; Schwab et al., 2000). A uniform grid with a resolution of $10 \mathrm{~km}$ is used in the horizontal and 21- $\sigma$ levels in the vertical. The model is driven directly by the observed meteorological forces, including winds and heat flux. The wind stress is calculated using the GLERL method from Liu and Schwab (1987). The heat forcing included two parts: (1) the surface net heat flux; and (2) the penetrated short-wave irradiance (Beletsky and Schwab, 1998; Chen et al., 2001; Zhu et al., 2001).

\subsection{Boundary conditions}

The surface and bottom boundary conditions for the momentum equations are given by

$$
\begin{aligned}
& \left(\frac{\partial u}{\partial \sigma}, \frac{\partial v}{\partial \sigma}\right)=\frac{D}{\rho_{\mathrm{o}} A_{\mathrm{m}}}\left(\tau_{0 x}, \tau_{0 y}\right) ; \omega=0 ; \quad \text { and } \\
& \frac{\partial T}{\partial \sigma}=\frac{D}{\rho_{\mathrm{o}} c_{\mathrm{P}} A_{\mathrm{h}}}\left(Q-I_{\mathrm{o}}\right), \text { at } \sigma=0 \\
& \left(\frac{\partial u}{\partial \sigma}, \frac{\partial v}{\partial \sigma}\right)=\frac{D}{\rho_{\mathrm{o}} A_{\mathrm{m}}}\left(\tau_{\mathrm{b} x}, \tau_{\mathrm{b} y}\right) ; \omega=0 ; \quad \text { and } \\
& \frac{\partial T}{\partial \sigma}=0, \text { at } \sigma=-1
\end{aligned}
$$


where $\left(\tau_{\mathrm{o} x}, \tau_{\mathrm{o} x}\right)$ and $\left(\tau_{\mathrm{b} x}, \tau_{\mathrm{b} y}\right)=C_{\mathrm{d}} \sqrt{u^{2}+v^{2}}\left(u^{2}+\right.$ $\left.v^{2}\right)$ are the $x$ and $y$ components of surface wind and bottom stresses. The drag coefficient $C_{\mathrm{d}}$ at the bottom is determined by matching a logarithmic bottom layer to the model at a height $z_{\mathrm{ab}}$ above the bottom, i.e.

$C_{\mathrm{d}}=\max \left[k^{2} / \ln \left(\frac{z_{\mathrm{ab}}}{z_{0}}\right)^{2}, 0.0025\right]$

where $k=0.4$ is the Karman's constant and $z_{0}$ is the bottom roughness parameter, which is taken as $0.001 \mathrm{~m}$ in this study. $A_{\mathrm{m}}$ is the vertical eddy viscosity; $D$, the total water depth; $T$, the water temperature; $c_{\mathrm{P}}$, the specific heat of seawater; $\rho_{\mathrm{o}}$, the reference density; $Q_{\mathrm{n}}$, the net surface heat flux; and $I_{\mathrm{o}}$, the incident irradiance at the sea surface.

The surface and bottom boundary conditions for biological variables are given by

$$
\begin{aligned}
& \frac{\partial}{\partial \sigma}\left(P_{\mathrm{S}}, Z_{\mathrm{L}}, Z_{\mathrm{S}}, B, D_{\mathrm{S}}, P, S\right)=0 ; \\
& \frac{\partial P_{\mathrm{L}}}{\partial \sigma}=\frac{D}{A_{\mathrm{h}}} w_{P_{\mathrm{L}}} P_{\mathrm{L}} ; \quad \text { and } \quad \frac{\partial D_{\mathrm{P}}}{\partial \sigma}=\frac{D}{A_{\mathrm{h}}} w_{\mathrm{D}} D_{\mathrm{P}}, \\
& \text { at } \sigma=0,-1
\end{aligned}
$$

where $w_{P_{\mathrm{L}}}$ and $w_{\mathrm{D}}$ are the sinking velocities of $P_{\mathrm{L}}$ and $D_{\mathrm{P}}$.

\subsection{Design of numerical experiments}

Because of the limitation of 3-D interdisciplinary data in Lake Michigan, we started our numerical experiments at a 1-D site located at the Grand Haven station $\left(43^{\circ} 00^{\prime} \mathrm{N}\right.$ and $86^{\circ} 24^{\prime} \mathrm{W}$, see Fig. 1). This site is a GLERL/NOAA and EPA ecosystem monitoring station with a long-term record of both hydrological and biological data. The water depth at this station is $\approx 100 \mathrm{~m}$ and the location is considered to be a transitional site for sediment accumulation (Cahill, 1981). These facts suggest that little sediment resuspension would occur at this station, even during strong plume events. For this reason, we did not include the sediment term in the numerical experiments. The 3-D physical model experiments have shown that the horizontal advections and upwelling are generally one order of magnitude smaller offshore than near the coastal region. A 1-D approxima- tion, as a first step, is a practical starting point to test and calibrate the biological model.

The initial distribution of temperature was specified based on the climatological conditions in winter of 1994, which were vertically uniform everywhere. From January 1 to April 1 the water temperature was held constant at $2{ }^{\circ} \mathrm{C}$ in the model by eliminating surface heat flux for this period. During this period, the lake was slightly stratified with up to $80 \%$ ice coverage and colder surface water temperature $\left(<2{ }^{\circ} \mathrm{C}\right)$ in open water areas. Since we did not have information about the vertical temperature structure during this period, we chose to use uniform $2{ }^{\circ} \mathrm{C}$ until April 1 when the satellite imagery showed surface water temperature was nearly uniform at $2{ }^{\circ} \mathrm{C}$. At that time, surface heat flux was restored in the model. This approximation should not have a significant effect on model results.

The initial distributions of biological variables also were specified using the climatological conditions in winter of 1994, in which phosphorus: 0.1 $\mu$ mol $P 1^{-1}$; silicon: $27 \mu \mathrm{mol} S_{i} 1^{-1}$; large phytoplankton: $0.5 \mu \mathrm{mol} C 1^{-1}$; small phytoplankton: $0.5 \mu \mathrm{mol} C 1^{-1}$; large zooplankton: $0.7 \mu \mathrm{mol} C$ $1^{-1}$; small zooplankton: $0.5 \mu \mathrm{mol} C 1^{-1}$; bacteria: $3.2 \mu \mathrm{mol} C 1^{-1}$; phosphorus-related detritus: 6.5 $\mu \mathrm{mol} C 1^{-1}$ and silicon-related detritus: $1.0 \mu \mathrm{mol}$ $C 1^{-1}$. Since the water was vertically well mixed in January 1994, the uniform initial values used for biological variables were a good approximation with little influence on the seasonal simulation results. The ratio of $C: P$ used in the model was 80 , which was the same value used by Parsons et al. (1984).

The coupled model was run using the 3-D code with five grid points in which all physical and biological variables were specified uniform in the horizontal. The numerical integration was conducted prognostically over a period of 2 years starting at the beginning of January 1, 1994.

\section{Model results}

\subsection{Physical structures}

The 1-D physical model captured the basic pattern of the seasonal variation of temperature 

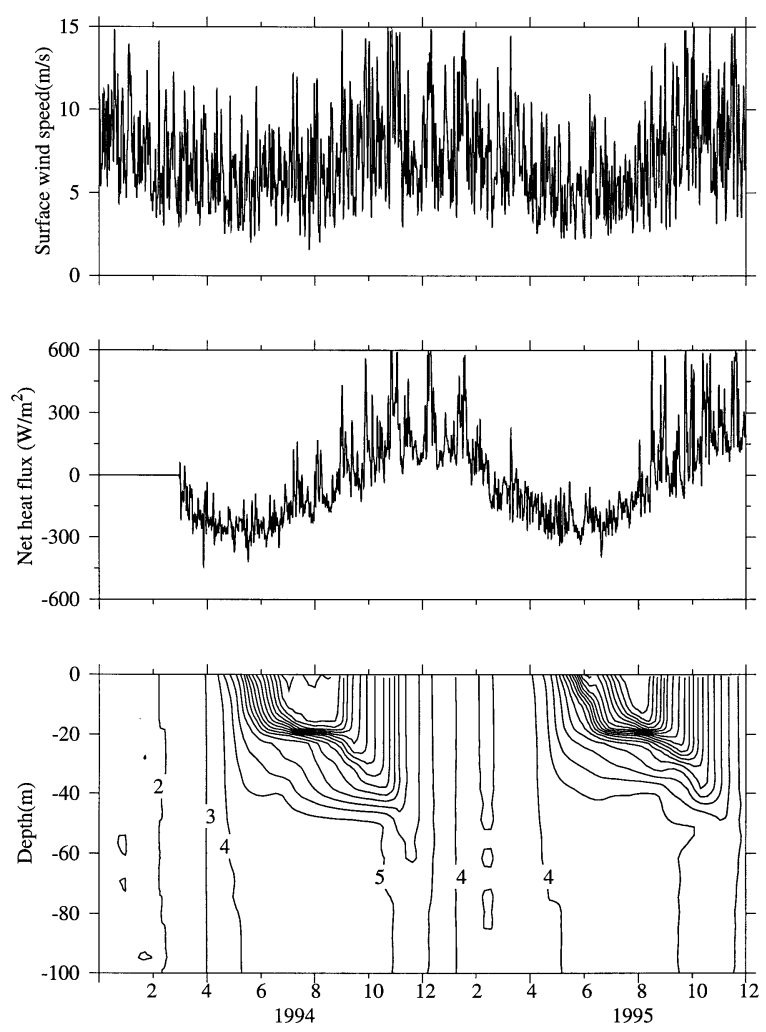

Fig. 3. Time series of the real-time wind speed (upper) and surface net heat flux (middle) and vertical distribution of model-predicted temperature (lower) in 1994 and 1995 at the Grand Haven monitoring station. A 40-h low-passed filter was used to treat the wind and heat flux data. The temperature interval was $1{ }^{\circ} \mathrm{C}$.

at Grand Haven station (Fig. 3). In 1994, stratification developed in early June as a result of surface heating. A continuous warming tendency caused the water in the upper $40 \mathrm{~m}$ to be well stratified in late June. The wind-induced mixed layer, defined as a layer in which vertical temperature difference is $<2.5{ }^{\circ} \mathrm{C}$, formed in early July and then gradually deepened with time through summer. Cold-front events with strong wind mixing and cooling occurred episodically in autumn, which caused a rapid increase of the thickness of the mixed layer. Correspondingly, a well-defined thermocline formed at depths of 15-20 $\mathrm{m}$ in early June and then deepened gradually to $\approx 25 \mathrm{~m}$ in late August. The intensity of the thermocline de- creased considerably in mid-August though early September and then disappeared in late October. A similar seasonal pattern also was found in 1995, except that the onset of thermal stratification occurred $\approx 10$ days earlier.

The model-predicted temperature is in good agreement with the observations taken at depths of 12, 25, 37 and $67 \mathrm{~m}$ (Fig. 4). Based on these agreements, the model results suggest that 1995 had a warmer winter and summer compared with 1994. The difference in temperature between these 2 years was $\approx 2{ }^{\circ} \mathrm{C}$ in winter and $5{ }^{\circ} \mathrm{C}$ in summer. It is not surprising that the model-predicted temperature curve is much smoother than the observed temperature curve, since the model is only 1-D and the model predicted field is
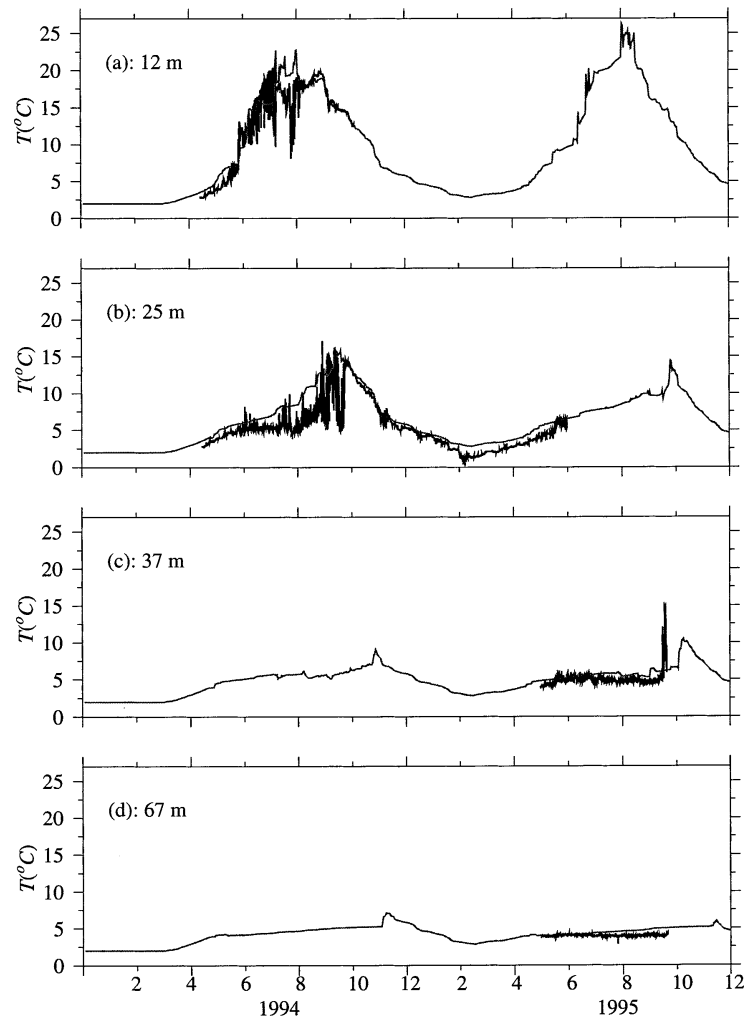

Fig. 4. Comparison between observed (heavy solid) and model-predicted (thin-solid) temperatures at selected depths of $12,25,37$ and $67 \mathrm{~m}$. 

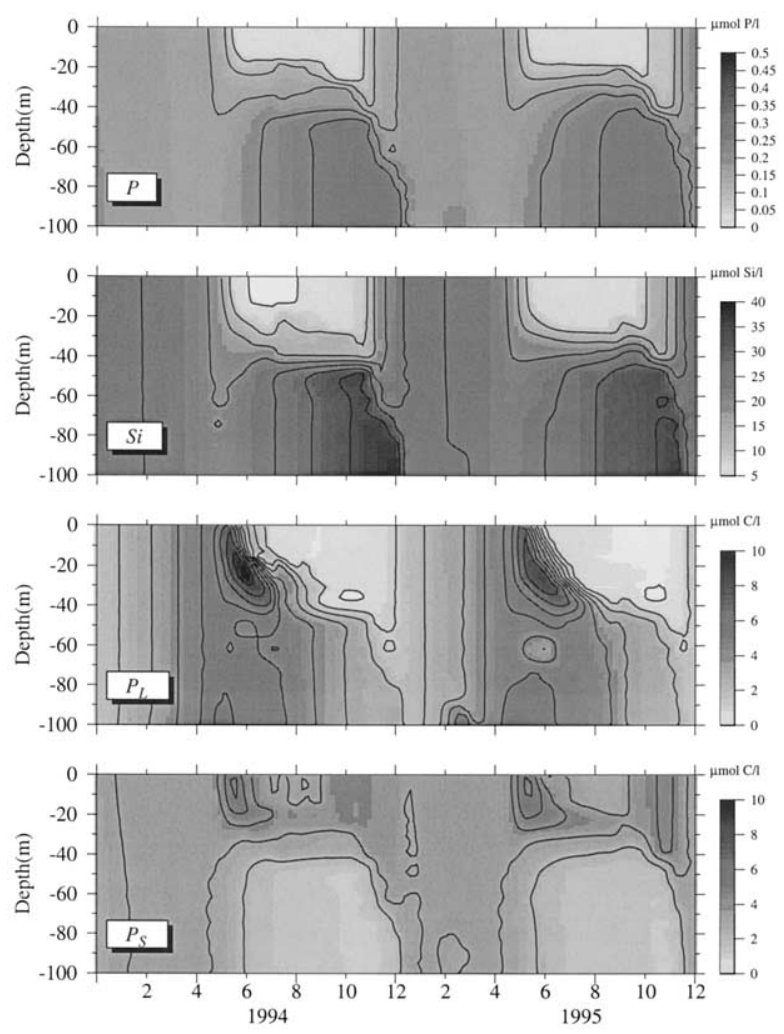

Fig. 5. Time sequences of the vertical distributions of phosphorus, silicon, small phytoplankton and large phytoplankton at the Grand Haven monitoring station over 1994-1995.

smoothed each time step to ensure the numerical stability.

\subsection{Seasonal distribution of biological variables}

The model-predicted seasonal variation of biological variables is closely associated with the seasonal distribution of temperature (Figs. 5 and 6). In 1994, both phosphate and silica concentrations in the upper $20 \mathrm{~m}$ decreased rapidly in early May as stratification developed and then remained minimum within the mixed layer during summer through autumn as the thermocline formed. Relatively large values of phosphate and silica were found below the thermocline in late summer and then concentrations vertically well mixed again in winter. This seasonal pattern was repeated in 1995, with slight variability due to the annual variation of stratification, as mentioned above.

Model-predicted large phytoplankton $P_{\mathrm{L}}$ grew rapidly in the upper $40 \mathrm{~m}$ in early May as stratification developed. A maximum value of $P_{\mathrm{L}}$ occurred near the surface in late May and then shifted to a depth of $30 \mathrm{~m}$ below the surface in late June. When the thermocline formed, $P_{\mathrm{L}}$ in the upper $40 \mathrm{~m}$ collapsed rapidly in a short period, starting near the surface and then extended downward. Subsequently, small phytoplankton $P_{\mathrm{S}}$ grew near the surface in late May, with remarkable variation in the mixed layer during summer. In summer through autumn, the biomass of $P_{\mathrm{L}}$ below the thermocline remained at a relatively high, decreasing slightly with time. An opposite structure was found in $P_{\mathrm{S}}$, which had a relatively low biomass and was vertically well mixed in the deep region just below the thermocline. Similar pat-
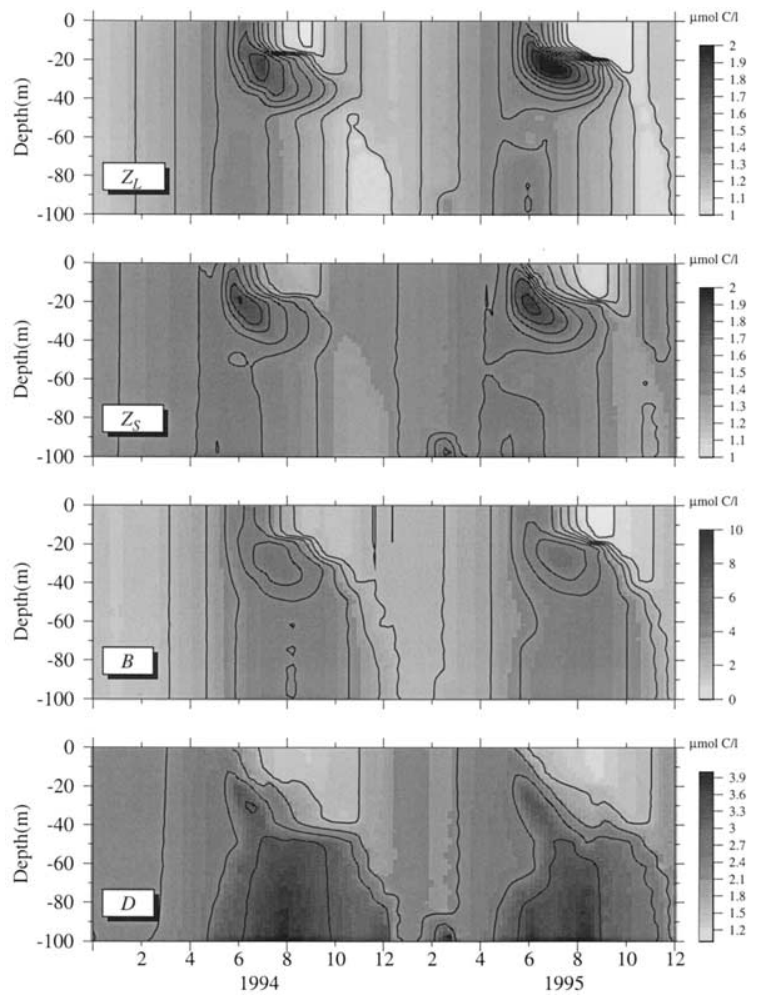

Fig. 6. Time sequences of the vertical distributions of small zooplankton, large zooplankton, bacteria and total detritus at the Grand Haven monitoring station over 1994-1995. 
terns of $P_{\mathrm{L}}$ and $P_{\mathrm{S}}$ appeared in 1995, suggesting a closely linkage with the seasonal variation of stratification.

Seasonal distributions of large and small zooplankton $\left(Z_{\mathrm{L}}\right.$ and $\left.Z_{\mathrm{S}}\right)$ were cohered well with seasonal patterns of $P_{\mathrm{L}}$ and bacteria $(B)$. In 1994 and $1995, B$ abundance grew significantly in the subsurface in late May and June as stratification developed and remained lower within the mixed layer in summer through autumn. The abundance became vertically uniform in winter as a result of wind mixing and surface cooling. Similar seasonal patterns were also found for $Z_{\mathrm{L}}$ and $Z_{\mathrm{S}}$, even though the maximum biomass of these two variables was about four times smaller.

Total detritus $(D)$ was vertically well mixed in the winter of 1994. It significantly increased in early May as stratification developed. Similar to other biological variables, the total $D$ remained at a minimum in the mixed layer in summer through autumn. Two extreme values of total $D$ were found over seasons: one was at the depth of $35 \mathrm{~m}$ in late June and the other near the bottom in late August. Tracing back to two separate components of detritus, we found that the subsurface maximum was dominated by the phosphorus-related component and the bottom extreme detritus mainly came from the silicon-related component.

\subsection{Mean biomass and flux}

The model-predicted mean biomass of each biological variable in the euphotic zone was estimated in the three dynamical phases which were defined based on the temporal variation of the thermocline. Phase I: a period with a rapid development of the thermocline; phase II: the duration with a fully developed thermocline and a nearconstant mixed layer depth; and phase III: a collapse period of the thermocline. The mean concentrations of $P$ and $S_{i}$ were $0.11 \mu \mathrm{mol} P 1^{-1}$ and $14.76 \mu \mathrm{mol} S_{i} 1^{-1}$ in phase I, $0.09 \mu \mathrm{mol} P 1^{-1}$ and $9.38 \mu \mathrm{mol} S_{i} 1^{-1}$ in phase II and $0.08 \mu \mathrm{mol} P$ $1^{-1}$ and $9.36 \mu \mathrm{mol} S_{i} 1^{-1}$ in phase III (Fig. 7a,b). The mean biomasses of $P_{\mathrm{L}}$ and $P_{\mathrm{S}}$ were 6.33 and $3.79 \mu \mathrm{mol} C 1^{-1}$ in phase I, 2.28 and $3.08 \mu \mathrm{mol} C$ $1^{-1}$ in phase II and 0.31 and 3.42 in phase III (Fig. 7c,d). Similarly, the mean biomasses of $Z_{\mathrm{L}}$,
$Z_{\mathrm{S}}, B$ and $D$ were $1.41,1.50,2.84$ and $5.54 \mu \mathrm{mol}$ $C 1^{-1}$ in phase I, $1.52,1.52,2.53$ and $3.80 \mu \mathrm{mol} C$ $1^{-1}$ in phase II and $1.29,1.28,2.27$ and $1.91 \mu \mathrm{mol}$ $C 1^{-1}$ in phase III, respectively (Fig. 7e-h). The model results suggested significant seasonal variations of large phytoplankton and detritus, but not for small phytoplankton, small and large zooplankton. The model-predicted bacteria had its maximum in spring and then gradually and slowly decreased over summer through autumn, which is consistent with recent finding from the direct measurement (Cotner et al., 2000; Biddanda et al., 2001).

The averaged phosphate-based mean flux of each biological process in the euphotic zone for the three phases is indicated in Fig. 8. The modelpredicted mean flux of phosphorus to $P_{\mathrm{S}}$ exhibits a small variation from spring through autumn, with the values of $1.47 \times 10^{-3}$ umol $P^{1^{-1}}$ per day in phase I, $1.22 \times 10^{-3}$ umol $P 1^{-1}$ per day in phase II and $1.51 \times 10^{-3}$ umol $P 1^{-1}$ per day in phase III. These values are about two or three times larger than the sum of the mean fluxes to $P_{\mathrm{L}}$ and $B$ in all three phases, implying that the uptake of the phosphorus by small phytoplankton was a major consumer of phosphorus. The mean flux to $Z_{\mathrm{L}}$ varied with season, coming comparably from $P_{\mathrm{L}}$ and $Z_{\mathrm{S}}$ in phase $\mathrm{I}$ and being dominated by $Z_{\mathrm{S}}$ in phases II and III. There was a net flux from $D$ to $B$, which was about eight to nine times larger than the flux from phosphorus to $B$. Most of the flux from detritus and phosphorus were taken by $Z_{\mathrm{S}}$ and a net flux in the $D$ and $P$ to $B$ and to $Z_{\mathrm{S}}$ implied that $B$ increased in phase $\mathrm{I}$, decreased in phase II and then slightly increased in phase III. The decrease of phosphorus in the euphotic zone was evident in the net loss of phosphorus flux after compensation by the remineralization process from detritus, though the model showed that the total $P$ in the water column remained constant.

Linking all these fluxes together suggest that after the thermocline was fully developed the secondary production could be attributed mainly to the detritus-bacteria-small zooplankton-large zooplankton loop, with little influences from the primary production of phytoplankton. This means that in summer and fall the zooplankton 

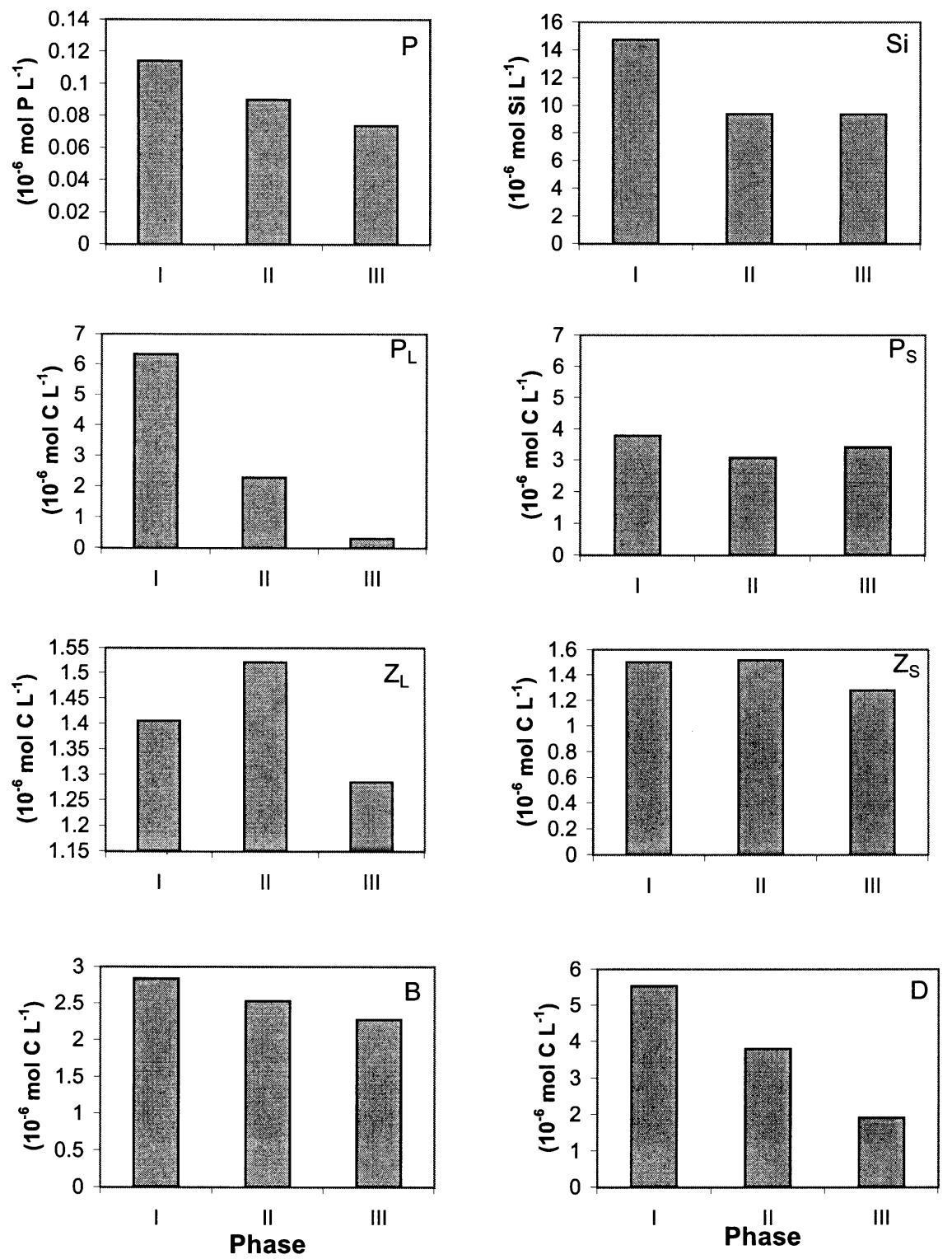

Fig. 7. The averaged biomasses of phosphorus, silicon, large phytoplankton and small phytoplankton, large zooplankton, small zooplankton, bacteria and total detritus in the euphotic layer during phases I-III.

processes could be separated from phytoplankton processes in southern Lake Michigan as a first order approximation. This model result is consistent with the suggestion from previous observations (Carrick et al., 1991), which showed that a larger carbon flux from heterotrophic bacteria to protozoans and copepods gained more carbon from ciliates than from diatoms. Our modeling experiments agree that the microbial food web plays a critical role in the ecosystem in Lake Michigan. These results are also consistent with recent measurements taken in the springtime plume in southern Lake Michigan (Cotner et al., 2000). 


\subsection{Comparison with observations}

The model-predicted vertical and seasonal distributions of nutrients and phytoplankton agree with the field measurement taken in 1994-1995 at the Grand Haven station (Fig. 9). Silicon was vertically uniform in winter, rapidly decreased in the mixed layer in summer and decreased in the deep region in late summer and fall and then mixed vertically again in late fall and subsequent winter. These features are captured in our 1-D modeling experiment. The model predicts a sharp vertical gradient of silicon in the thermocline area, which was unresolved in the observational data because of a coarse sampling resolution in the vertical. The observations also show that chloro- phyll- $a$ was uniform vertically in winter, grew significantly and reached a maximum at the subsurface in early June and was then depleted in summer. These vertical and seasonal features also are evident in the model-predicted total phytoplankton biomass.

The model-predicted, depth-averaged silicon and chlorophyll concentrations coincide well with the seasonal distribution of silicon and chlorophyll- $a$ (Fig. 10). The model results show that depth-averaged concentration of silicon reached a minimum level of $16.5 \mathrm{umol} S_{i} 1^{-1}$ in late June for both 1994 and 1995 and a maximum level of 25 umol $S_{i} 1^{-1}$ in January, which matched the seasonal distribution of observed silicon over 2 years. The model-predicted, depth-averaged chlorophyll

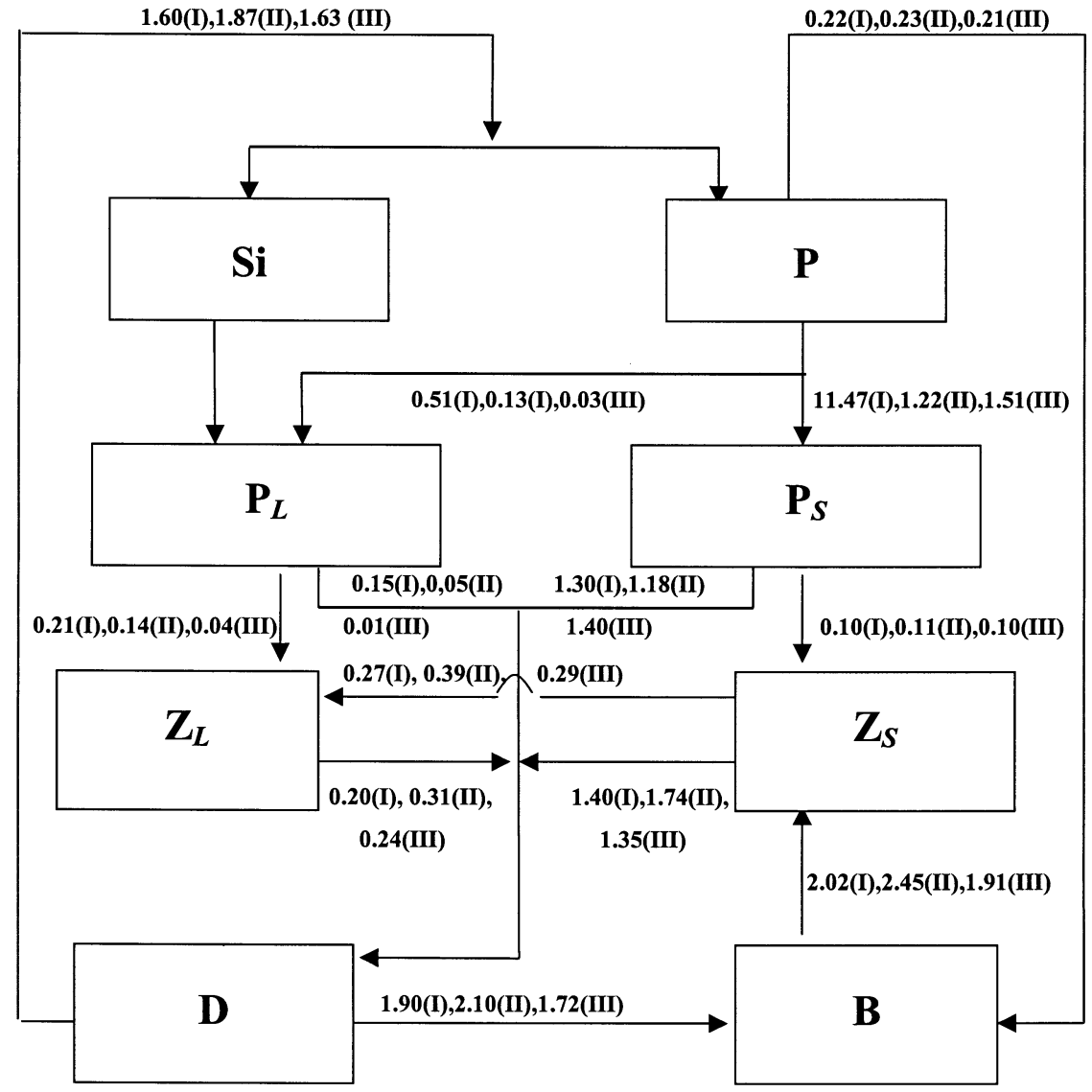

Fig. 8. The averaged fluxes of each biological variables within the lower trophic level food web system in the euphotic layer during phases I-III. The unit is $10^{-3} \mu \mathrm{mol} P 1^{-1}$ per day. 

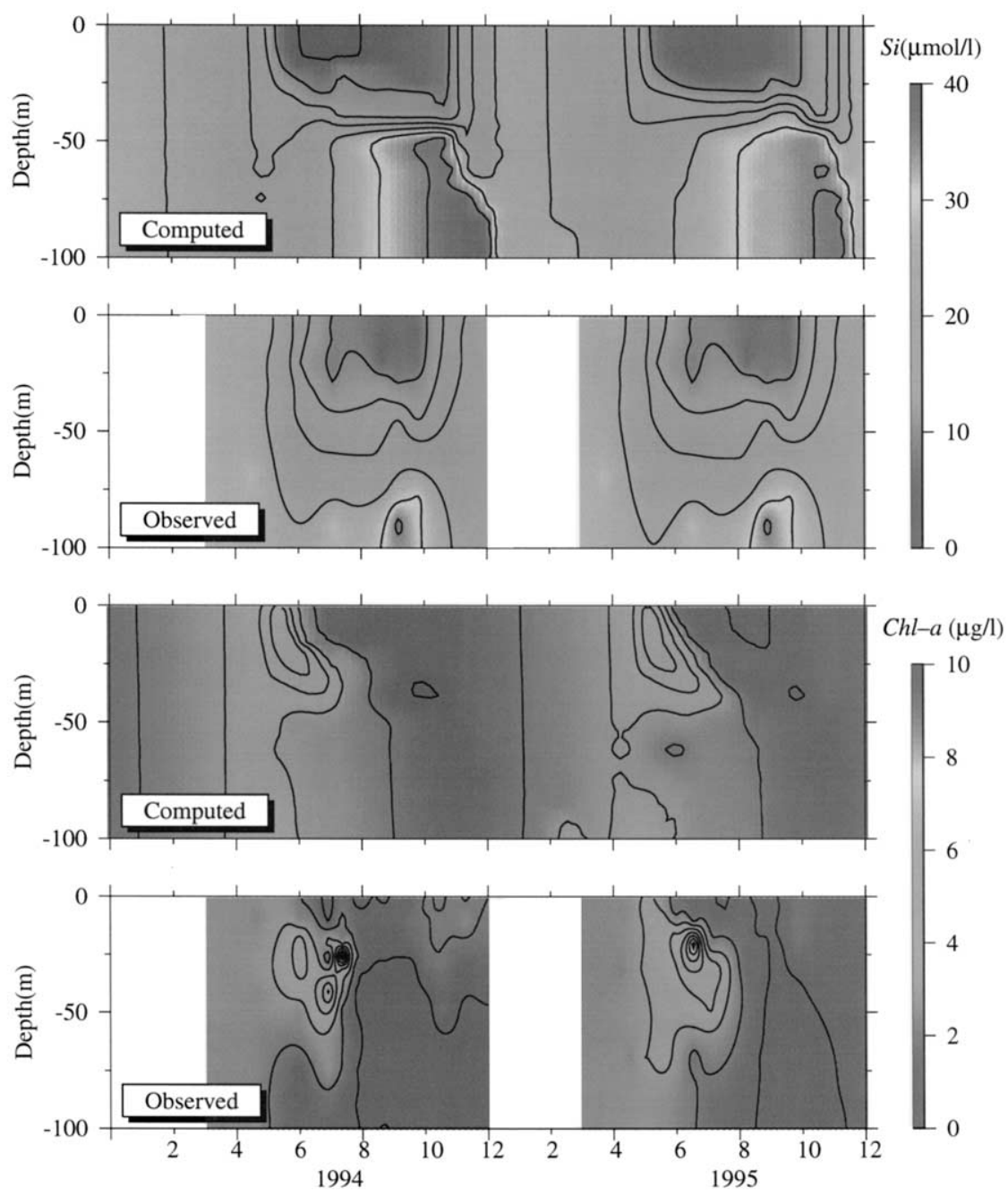

Fig. 9. Comparison between the vertical distributions of model-predicted and observed silicon and phytoplankton at the Grand Haven station over 1994-1995.

reached a maximum level of $3.9 \mathrm{ug} 1^{-1}$ in midJune and a minimum level of $1.4 \mathrm{ug} 1^{-1}$ in early November in 1994 and then again a maximum level of $3.7 \mathrm{ug} 1^{-1}$ in mid-June in the subsequent 1995. This model-predicted seasonal distribution of phytoplankton matches the observed chlorophyll- $a$ concentrations, especially in 1995.

The model results also are consistent with previous measurements taken in southern Lake Michigan. Chlorophyll- $a$ concentration at a sta- tion $12.9 \mathrm{~km}$ offshore the Grand River was $\approx$ $3.5 \mathrm{ug} 1^{-1}$ during summer and $2.4 \mathrm{ug} 1^{-1}$ in autumn (Moll and Brache, 1986). The depth-averaged chlorophyll- $a$ in 1986-1989 varied in a range of $0.5-2.5 \mathrm{ug}^{-1}$ from winter to summer (Brooks and Edington, 1994). Taking the annual variation of stratification into account, the model-predicted silicon and phytoplankton represent the general seasonal pattern of nutrients and phytoplankton in southern Lake Michigan. 
A deep chlorophyll layer (DCL) which developed after the onset of seasonal stratification was discovered in 1984-1985 (Fahnenstiel and Scavia, 1987a). The DCL initially occurred in $15-30 \mathrm{~m}$ below the surface, deepened to $25-50$
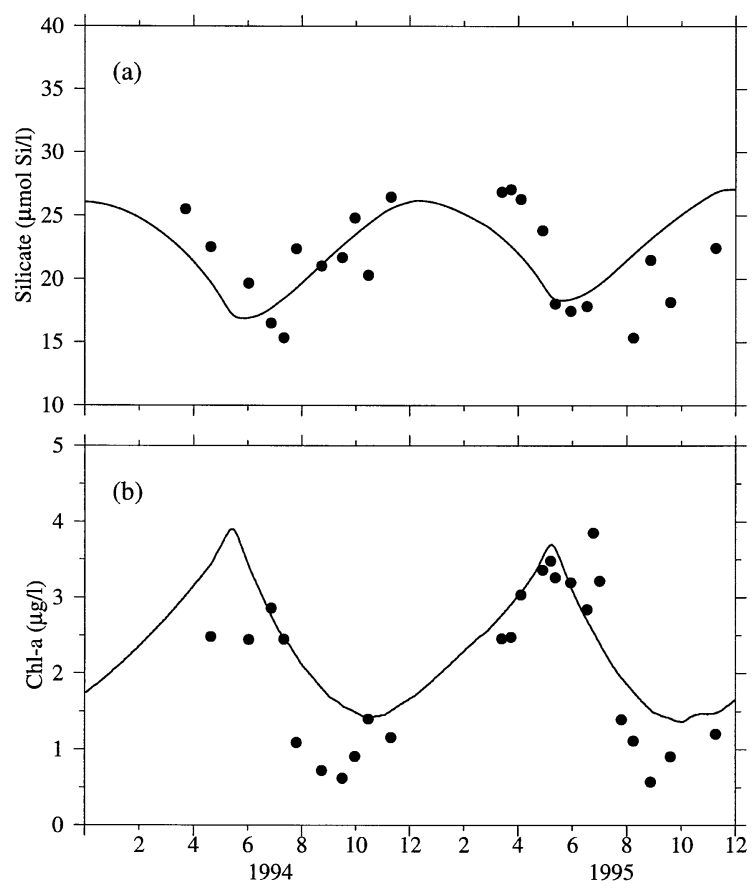

Fig. 10. Comparisons between the model-predicted and observed depth-averaged silicon (a) and phytoplankton (b) over 1994-1995.

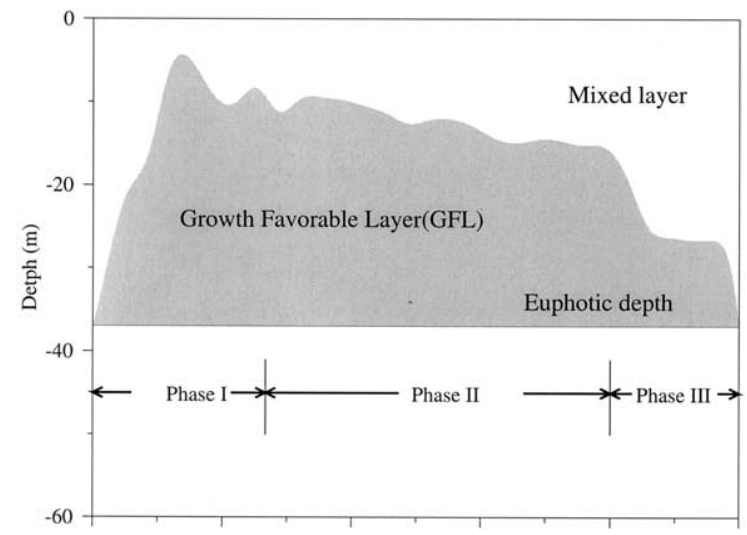

Fig. 11. The temporal distribution of the surface mixed layer, growth favorable layer and euphotic layer over phase I-III. $\mathrm{m}$ in July and then to $40-70 \mathrm{~m}$ in August. About $50 \%$ of primary production in summer occurred below the epillimnion. Our 1-D model clearly show that the maximum layer of phytoplankton began to develop as stratification developed. It was near the surface at the beginning, gradually deepened to $30 \mathrm{~m}$ in late June and then to $45 \mathrm{~m}$ in late August.

A sensitivity study was conducted to test the model reliability to uncertainties in bio-parameters. For a given light attenuation, the measure indices of sensitivity for all bio-parameters were $<0.5$ regarding the influence on the mean biomass. This suggests that the model-predicted seasonal pattern of biological variables were robust. A detailed discussion of the sensitivity analysis is given in Appendix B.

\section{Discussion}

Our model reveals that the large phytoplankton in the euphotic layer grew rapidly in spring and early summer and was then depleted through summer through autumn. This seasonal pattern was associated with the formation and collapse of the seasonal thermocline. The thickness of the well-defined mixed layer was generally smaller than the euphotic layer in southern Lake Michigan (Fig. 11). This suggests the existence of a growth favorable layer (GFL) between the bottom of the mixed layer and the lower base of the euphotic layer. Based on the field measurements taken in southern Lake Michigan, Fahnenstiel and Scavia (1987a) suggested that the GFL worked as an area of nutrients, which directly supported the occurrence of deep chlorophyll- $a$ layer (DCL) in the thermocline. To examine the relative importance of biological and physical processes in the seasonal variation of large phytoplankton in southern Lake Michigan, we estimated the total flux of each term in large phytoplankton and silicon equations in the euphotic layer and deep region over spring through autumn of 1994. In a 1-D case, for example, Eq. (1) and Eq. (9) in the euphotic layer can be rewritten as integrated forms as follows 


$$
\begin{aligned}
& \left.P_{\mathrm{L}}\right|_{t}-\left.P_{\mathrm{L}}\right|_{t_{\mathrm{o}}} \\
& =\int_{t_{\mathrm{o}}}^{t} \int_{-\mathrm{h}_{\mathrm{E}}}^{0} \mathrm{~L} P(\text { uptake }) d z d t^{\prime} \\
& \quad-\int_{t_{\mathrm{o}}}^{t} \int_{-\mathrm{h}_{\mathrm{E}}}^{0} \mathrm{~L} P(\text { mortality }) d z d t^{\prime} \\
& \quad-\int_{t_{\mathrm{o}}}^{t} \int_{-\mathrm{h}_{\mathrm{E}}}^{0} \mathrm{~L} Z \mathrm{~L} P(\text { grazing }) d z d t^{\prime}-\left.\left(W_{\mathrm{S}} P_{\mathrm{L}}\right)\right|_{-\mathrm{h}_{\mathrm{E}}} \\
& \quad-\left.A_{\mathrm{h}} \frac{\partial P_{\mathrm{L}}}{\partial z}\right|_{-\mathrm{h}_{\mathrm{E}}}(14) \\
& \left.S_{i}\right|_{t}-\left.S_{i}\right|_{t}=-\sigma_{\mathrm{S}} \int_{t_{\mathrm{o}}}^{t} \int_{-\mathrm{h}_{\mathrm{E}}}^{0} \mathrm{LP}(\text { uptake }) d z d t^{\prime} \\
& \left.\quad+\int_{t_{\mathrm{o}}}^{t} \int_{-\mathrm{h}_{\mathrm{E}}}^{0} D \mathrm{~S} \text { (remineralization) }\right) d z d t^{\prime} \\
& \quad-\left.A_{\mathrm{h}} \frac{\partial S_{i}}{\partial z}\right|_{-\mathrm{h}_{\mathrm{E}}}
\end{aligned}
$$

Similarly, we can derive the integrated forms of $P_{\mathrm{L}}$ and $S_{i}$ in the deep layer with an upper boundary at the base of the euphotic layer as

$$
\begin{aligned}
& \left.P_{\mathrm{L}}\right|_{t}-\left.P_{\mathrm{L}}\right|_{t_{\mathrm{o}}} \\
& =\int_{t_{\mathrm{o}}}^{t} \int_{-H}^{-\mathrm{h}_{\mathrm{E}}} \mathrm{L} P(\text { uptake }) d z d t^{\prime} \\
& \quad-\int_{t_{\mathrm{o}}}^{t} \int_{-H}^{-\mathrm{h}_{\mathrm{E}}} \mathrm{L} P(\text { mortality }) d z d t^{\prime} \\
& \quad-\int_{t_{\mathrm{o}}}^{t} \int_{-H}^{-\mathrm{h}_{\mathrm{E}}} \mathrm{L} Z \mathrm{~L} P(\text { grazing }) d z d t^{\prime}+\left.\left(W_{\mathrm{S}} P_{\mathrm{L}}\right)\right|_{-\mathrm{h}_{\mathrm{E}}} \\
& \quad+\left.A_{\mathrm{h}} \frac{\partial P_{\mathrm{L}}}{\partial z}\right|_{-\mathrm{h}_{\mathrm{E}}} \\
& \left.S_{i}\right|_{t}-\left.S_{i}\right|_{t_{\mathrm{o}}}=-\sigma_{\mathrm{S}} \int_{t_{\mathrm{o}}}^{t} \int_{-H}^{-\mathrm{h}_{\mathrm{E}}} \mathrm{L} P(\text { uptake }) d z d t^{\prime} \\
& \quad+\int_{t_{\mathrm{o}}}^{t} \int_{-H}^{-\mathrm{h}_{\mathrm{E}}} D \mathrm{~S}(\text { remineralization }) d z d t^{\prime} \\
& \quad+\left.A_{\mathrm{h}} \frac{\partial S_{i}}{\partial z}\right|_{-\mathrm{h}_{\mathrm{E}}}
\end{aligned}
$$

In the euphotic layer, in phase $\mathrm{I}, P_{\mathrm{L}}$ grew rapidly in May through mid-June at the onset of thermal stratification and then depleted quickly in late June and July as the thermocline strengthened and deepened. Although the growth rate of $P_{\mathrm{L}}$ increased significantly in this phase, it was smaller than the total loss caused by phytoplankton mor- tality, sinking and zooplankton grazing after late June. The temporal variation of $P_{\mathrm{L}}$ with time was mainly dominated by internal biological processes with very little contribution from vertical diffusion (Figs. 12(a) and 13). $P_{\mathrm{L}}$ continued to decrease in phase II due to a net loss through phytoplankton mortality, sinking and zooplankton grazing against a small growth. In phase III, the change of $P_{\mathrm{L}}$ was slow down and vertical diffusion became a first order contributor. The rapid decrease of $P_{\mathrm{L}}$ in the euphotic layer in the late past of phase I and entire phase II was related to a rapid decrease of $S_{i}$ in phase I and limited abundance in phase II. In phase I, phytoplankton uptake was much larger than nutrient regeneration from detritus remineralization and supply rates from the deep layer through vertical diffusion and was the dominant sink for $S_{i}$. In phases II and III, $S_{i}$ remained consistently low because the uptake rate of nutrient, remineralization and vertical diffusion were all small. Unlike phytoplankton, vertical diffusion played the same role as remineralization in the temporal variation of nutrients in the euphotic layer.

In the deep layer, $P_{\mathrm{L}}$ decreased gradually in phases II and III after the thermocline developed. This phenomenon was mainly caused by a net loss through phytoplankton mortality and zooplankton grazing via phytoplankton sinking and vertical diffusion. A relatively high nutrient pool formed in the deep region in phases II and III was caused by particle sedimentation and subsequent nutrient remineralization. The existence of a large detritus pool in the deep layer resulted from materials left after zooplankton grazing and death of large phytoplankton.

The integrated structure of $P_{\mathrm{L}}$ and $S_{i}$ in the euphotic zone also represented the general features of $P_{\mathrm{L}}$ and $S_{i}$ in the favorable growth layer (FGL) since the flux through the mixed layer to the FGL was much smaller. In our model experiment, the formation of DCL in the thermocline during early summer was mainly caused by a rapid increase of the phytoplankton uptake and phytoplankton sinking and it disappeared in late summer due to the suppression of silicon supplies from the deep region as the thermocline developed. The physical diffusion process was important for the nutrient supply from the deep region to the euphotic layer, but it could be ignored in 


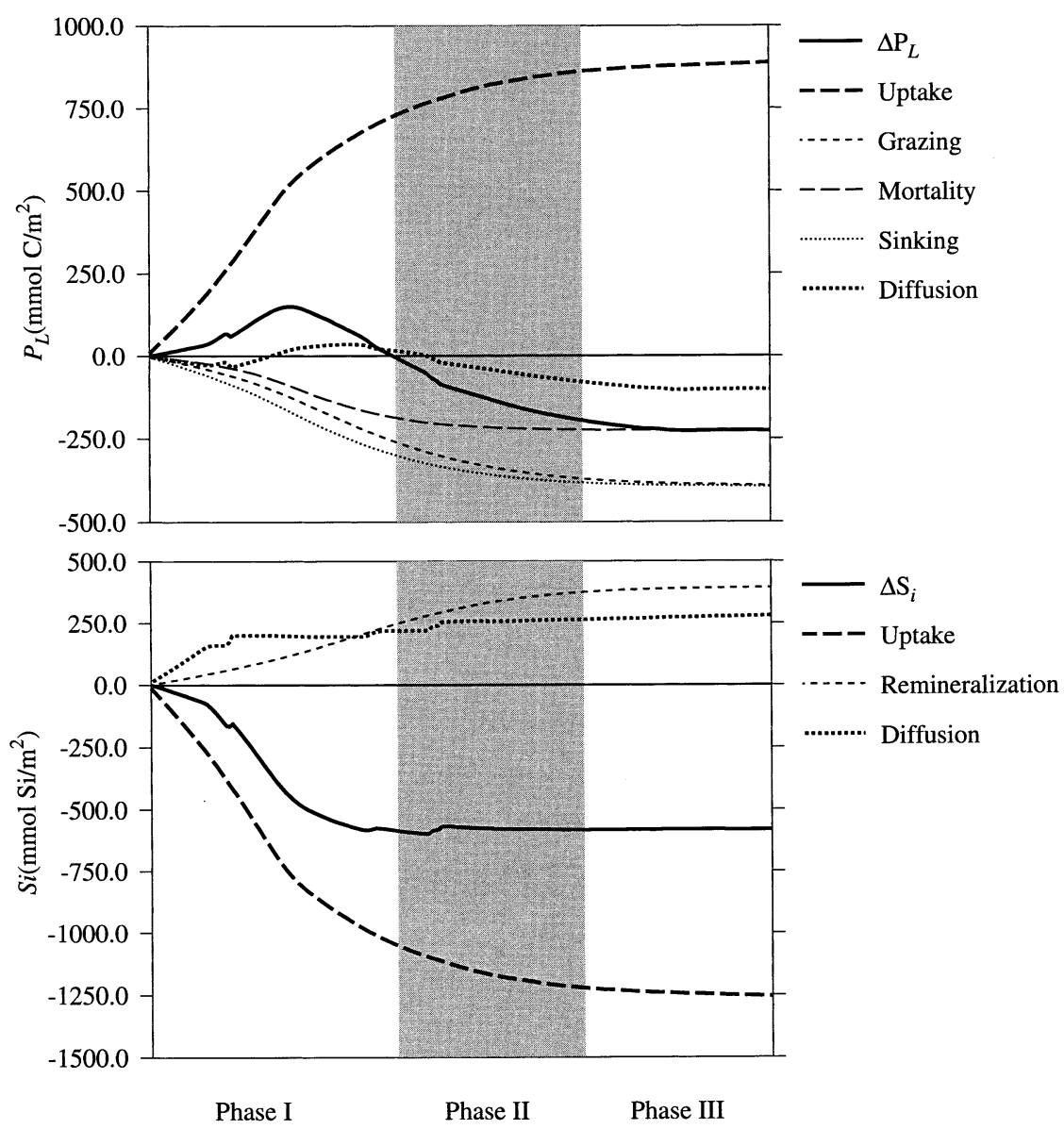

Fig. 12. Time series of each term in Eq. (14) and Eq. (15) over phases I-III for the euphotic layer.

the temporal variation of phytoplankton as a first order approximation.

Our 1-D model suggested that the microbial food web might play an important role in the lower trophic food web system in southern Lake Michigan. A much larger flux from $D$ to $B$ than from $P$ to $B$ and from $B$ to $Z_{\mathrm{S}}$ than from $P_{\mathrm{S}}$ to $Z_{\mathrm{S}}$, suggested a detritus-bacteria-microzooplankton loop that was decoupled from phytoplankton and nutrients. Also, there was a relatively large grazing rate of $Z_{\mathrm{S}}$ by $Z_{\mathrm{L}}$ in phases II and III after the thermocline developed, implying that zooplankton dynamics might be decoupled from phytoplankton and nutrients in summer and autumn in southern Lake Michigan. These modeling findings are qualitatively consistent with previous observations in Lake Michigan (Carrick et al., 1991) and recent EEGLE field measurements taken in southern Lake Michigan. We understand that the reliability of these suggestions depends on the choice of biological parameters. Sensitivity analysis conducted in Appendix B showed that changing biological parameters had no significant impact on the biomass of each biological variable, and secondary production was not sensitive to the maximum nutrient uptake rates of large phytoplankton and bacteria, which to a certain extent supports a decoupled food web system between nutrients-phytoplankton and bacteria-micozooplankton-zooplankton. In addition, a good agreement between model-predicted and observed nutrients and phytoplankton 
distributions over 1994-1995, indirectly implied that those parameters chosen in the model was reasonable.

Our 1-D experiments revealed that physical forcing (wind mixing and surface heating/cooling) was a key controlling factor for the seasonal structure of biological variables in southern Lake Michigan. The formation and collapse of the DCL was related to the seasonal development of the surface mixed layer as well as the thermocline, which was simulated reasonably by our physical model. It should also be pointed out here that the 1-D model missed wind-induced upwelling or downwelling and horizontal advection in the coastal region, which were important in simulat- ing the 3-D nature of the biological field in the coastal region where the episodic plume occurred.

\section{Summary}

A coupled physical and biological model was developed for Lake Michigan. The physical model was the Princeton ocean model (POM), which was driven directly by observed winds and surface heat flux. The biological model was an eight-component, phosphorus-limited, lower trophic food web model that included phosphate and silicate for nutrients, diatoms and non-diatoms for dominant phytoplankton species, copepods and hetero-
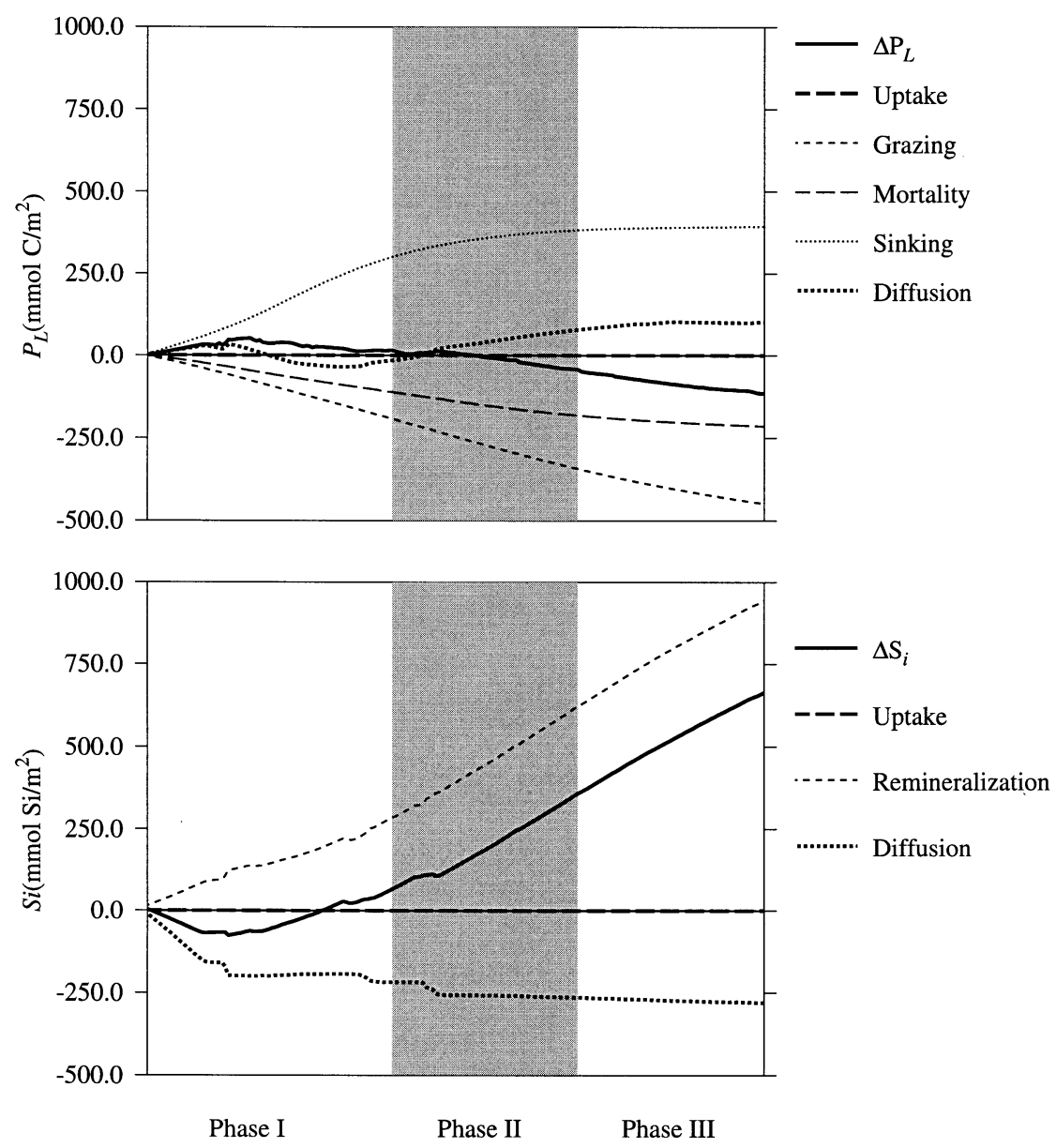

Fig. 13. Time series of each term in Eq. (15) and Eq. (16) over phases I-III for the deep layer. 
trophic flagellates for dominant zooplankton species, bacteria and detritus.

Driven by observed meteorological forcings, a 1-D modeling experiment was conducted at the Grand Haven monitoring station for a 2-year period from 1994 to 1995 . The model showed that the large phytoplankton (diatoms) significantly grew in the subsurface region in early summer as stratification developed and then decayed rapidly in the mixed layer with the reduction of silicate supplied from the deep stratified region as a result of the formation of the thermocline. The small phytoplankton (non-diatoms) subsequently grew in mid and late summer under a limited-phosphate environment and then reduced rapidly in the fall and winter as results of the nutrient consumption in the upper eutrophic layer, limitation of nutrients supplied from the deep region, and meteorological cooling and wind mixing. The flux estimates suggested that the microbial loop had a significant contribution to the growth of microzooplankton. The food web system might be divided into two decoupled loops: (1) detritusbacteria-microzooplankton-large zooplankton; and (2) nutrient-phytoplankton-detritus.

Sensitivity analysis suggested that changing the biological parameters had no significant impacts on the biomass of each biological parameter. The most sensitive parameters were $V_{\max }^{P_{\mathrm{L}}}$ and $k_{P_{\mathrm{L}}}$ for primary production, and $V_{\max }^{\mathrm{DOP}}, k_{\mathrm{DOP}}$ and $\alpha^{B^{\mathrm{L}}}$ for secondary production. These parameters must be estimated accurately from the field measurements or laboratory experiments in order to make the model robust and applicable to Lake Michigan.

\section{Acknowledgements}

This research was supported by the NSF/ NOAA EGGLE Program under the NSF grant number OCE-9712869 for Changsheng Chen, OCE-9712872 for J.W. Budd, NOAA Coastal Ocean Program grant for D.J. Schwab, D. Beletsky, G.L. Fahnenstiel, J. Cotner, T.H. Johengen, B. Eadie, H. Vanderploeg, W. Gardner and P.J. Lavrentyev and under the NSF grant number OCE-9730416 for M.H. Bundy. R. Ji and M. Jiang are supported by Chen's NSF grant.

\section{Appendix A. The biological model}

The mathematical expression for each term in the biological model shown in Eqs. (1)-(9) are given below:

$$
\begin{aligned}
& \text { LP(uptake) } \\
& =\min \left(V_{\max }^{P_{\mathrm{L}}} \frac{P}{k_{P_{\mathrm{L}}}+P}, V_{\max }^{S} \frac{S}{k_{\mathrm{S}}+S}\right) f(I) P_{\mathrm{L}} \\
& \mathrm{L} Z \mathrm{~L} P(\text { grazing })=G_{\max }^{Z_{\mathrm{L}}}\left(1-\mathrm{e}^{-k^{P} \mathrm{~L}_{\mathrm{L}}}\right) Z_{\mathrm{L}} \\
& \mathrm{S} P(\text { uptake })=V_{\max }^{P_{\mathrm{s}}} \frac{P}{k_{P_{\mathrm{L}}}+P} f(I) P_{\mathrm{s}} \\
& \mathrm{S} Z \mathrm{~S} P(\text { grazing })=G_{\max }^{Z_{\mathrm{s}}}\left(1-\mathrm{e}^{-k^{P_{\mathrm{s}} P_{\mathrm{s}}}}\right) Z_{\mathrm{s}} \\
& \mathrm{L} Z \mathrm{~S} Z(\text { grazing })=G_{\max }^{Z_{\mathrm{LS}}}\left(1-\mathrm{e}^{-k^{Z_{\mathrm{LS}}} Z_{\mathrm{s}}}\right) Z_{\mathrm{L}} \\
& \mathrm{S} Z B(\text { grazing })=G_{\max }^{B}\left(1-\mathrm{e}^{-k^{B} B}\right) Z_{\mathrm{s}} \\
& B P(\text { uptake })=V_{\max }^{B} \frac{P}{k_{B}+P} B \\
& D B(\text { decomposition })=V_{\max }^{\mathrm{DOP}} \frac{\mu_{\mathrm{D}} D}{k_{\mathrm{DOP}}+\mu_{\mathrm{D}} D} \\
& \mathrm{~S} Z B(\text { grazing })=G_{\max }^{B}\left(1-\mathrm{e}^{-k^{B} B}\right) Z_{\mathrm{s}} \\
& D \mathrm{P}(\text { remineralization })=e_{\mathrm{P}} D_{\mathrm{P}} \\
& D \mathrm{~S}(\text { remineralization })=e_{\mathrm{s}} D_{\mathrm{s}} \\
& \mathrm{L} P(\text { sinking })=w_{P_{\mathrm{L}}} \frac{\partial P_{\mathrm{L}}}{\partial z} \\
& \mathrm{~L} P \text { (mortality) }=\alpha^{P_{\mathrm{L}}} P_{\mathrm{L}}^{2} \\
& \mathrm{~S} P(\text { mortality })=\alpha^{P_{\mathrm{s}}} P_{\mathrm{s}}^{2} \\
& \mathrm{~L} Z(\text { mortality })=\alpha^{Z_{\mathrm{L}}} Z_{\mathrm{L}}^{2} \\
& \mathrm{~S} Z(\text { mortality })=\alpha^{Z_{\mathrm{s}}} Z_{\mathrm{s}}^{2} \\
& B(\text { mortality })=\alpha^{B} B^{2}
\end{aligned}
$$

where the definition for each parameter used in the above equations is given in Table 1. $\sigma_{\mathrm{P}}$ and $\sigma_{\mathrm{s}}$ are the phosphorus and silica fractions of large phytoplankton (diatom) contained in the total amount of unassimilated zooplankton grazing, respectively and $\sigma_{\mathrm{P}}+\sigma_{\mathrm{s}}=1$. The value of $\sigma_{\mathrm{P}}$ was made according to the observed ratios of carbon to phosphorus in general plants and diatom and then $\sigma_{\mathrm{s}}$ was directly derived by $1-\sigma_{\mathrm{P}}$. 
The dependence of the phytoplankton growth rate on incident irradiance intensity $f(I)$ is given as

$f(I)=\mathrm{e}^{-k_{0} z}$

where $k_{0}$ is the diffuse attenuation coefficient. Eq. (A18) was normalized using the surface incident irradiance intensity. In general, the response of phytoplankton to light intensity varies according to different species. For many phytoplankton species, the photosynthesis reaches its saturation level at a certain level of light intensity and is then inhibited as light intensity continues to be stronger. The linear assumption of $\ln f(I)$, used widely in previous lower trophic level food web models, does not consider saturation and inhibition of photosynthesis via light. It was found to be a good approximation in a mixed region (Franks and Chen, 1996; Chen et al. 1997, 1999), but it should be aware of its limitation to reproduce the vertical profile of primary production which normally exhibits a maximum value at subsurface.

Instead of using a constant mortality rate, we concurred in assuming that the organism mortality was proportional to its biomass. A sensitivity analysis of biological model without inclusion of physical forcing has revealed that this mortality rate was robust to capture a conservative biological system under a condition with no extra sources and sinks.

Bacteria assimilation for dissolved organic phosphorus (DOP) was also assumed to follow the Michaelis-Menten function, in which DOP was proportional to the total detritus. This assumption was similar to make the bacteria graze detritus directly with a half-saturation constant of $k_{\mathrm{DOP}} / \mu_{\mathrm{D}}$. A large portion of bacterial ingestion, which may be excreted into particular organic pool, was taken into account in our numerical experiments by assuming a larger mortality rate of bacteria (Cotner and Wetzel, 1992).

Values of biological parameters used in our numerical experiments were listed in Table 1. These values were obtained from previous field measurements taken in Lake Michigan and the literature. Since biological parameters varied in a wide range with time and space, we first ran the model with an initial setup of parameters and then carried out a sensitivity analysis of parameter ranges. A detailed description of this sensitivity analysis is given in Appendix B.

\section{Appendix B. Sensitivity analysis}

The most difficult issue in the development of a biological model is to determine the bio-parameters, since they vary in a wide range with time and space for different species. To qualify the modelpredicted biological fields, a series of sensitivity analysis was conducted to test the model reliability to uncertainties in bio-parameters. The objective of this analysis, at first, was to find the most sensitive parameters for primary production (PP), secondary production (SP), and mean biomass, and then to evaluate if the model-predicted seasonal patterns of biological variables were robust.

The sensitivity of bio-parameters in our 1-D experiments was estimated by

$$
\hat{S}=\left|\frac{\Delta F / F}{\Delta \text { Parameter/Parameter }}\right|
$$

where $\hat{S}$ is a measure index of sensitivity, $F$ is the concentration of a biological variable in the model run with a standard set of biological parameters and $\Delta F$ is the change of $F$ caused by varying the model parameter. $\Delta$ Parameter is varied by $1 \%$ from the standard value. This method was the exact same as that used in Franks and Chen (1996), Fasham et al. (1990) and Chen et al. (1999). According to the definition used in those previous studies, one parameter is determined to be sensitive as its sensitivity index $\hat{S}$ is equal to or larger than 0.5 .

The resulting sensitivity indices for all bioparameters are listed in Table 2. For a given light attenuation $k_{0}, \hat{S}$ for all bio-parameters were $<$ 0.5 regarding the influence on the mean biomass. This result suggests that the model-predicted seasonal patterns of biological variables were robust. As long as the primary production was concerned, the most sensitive bio-parameters were $V_{\max }^{P_{\mathrm{L}}}$ and $k_{P_{\mathrm{L}}}$. This conclusion implied that the model might not provide a robust quantitative result of primary production due to the photosynthesis of 
Table 2

Sensitivity indices for bio-parameters

\begin{tabular}{|c|c|c|c|c|c|c|}
\hline Bio-parameter & Standard value & Testing value & Percent & $\begin{array}{l}\text { Primary } \\
\text { production }\end{array}$ & $\begin{array}{l}\text { Secondary } \\
\text { production }\end{array}$ & Mean biomass \\
\hline$V_{\max }^{P_{\mathrm{L}}}$ & 1.2 & 1.3 & 0.083 & 0.84 & 0.16 & 0.42 \\
\hline$V_{\max }^{P \mathrm{~S}}$ & 0.7 & 0.8 & 0.143 & 0.09 & 0.84 & 0.06 \\
\hline$V_{\max }^{S}$ & 1.2 & 1.3 & 0 & 0.04 & 0.04 & 0 \\
\hline$V_{\max }^{B}$ & 0.05 & 0.06 & 2 & 0.11 & 0.15 & 0 \\
\hline$V_{\max }^{\mathrm{DOP}}$ & 5 & 6 & 0.2 & 0.46 & 1.84 & 0.16 \\
\hline$k_{P_{\mathrm{L}}}$ & 0.2 & 0.15 & 0.25 & 0.51 & 0.03 & 0.22 \\
\hline$k_{P_{\mathrm{S}}}^{\mathrm{L}}$ & 0.05 & 0.06 & 0.2 & 0.01 & 0.29 & 0 \\
\hline$k_{\mathrm{S}}$ & 5 & 6 & 0.2 & 0.02 & 0.02 & 0 \\
\hline$k_{\mathrm{B}}$ & 0.2 & 0.25 & 0.25 & 0.04 & 0.09 & 0 \\
\hline$k_{\mathrm{DOP}}$ & 0.1 & 0.12 & 0.2 & 0.31 & 1.07 & 0.08 \\
\hline$G_{\max }^{Z_{\mathrm{L}}}$ & 0.4 & 0.35 & 0.125 & 0.38 & 0.18 & 0.27 \\
\hline$G_{\max }^{Z_{\mathrm{S}}}$ & 0.2 & 0.25 & 0.25 & 0.02 & 0.04 & 0.01 \\
\hline$G_{\max }^{B}$ & 3.5 & 3 & 0.143 & 0.20 & 0.50 & 0.02 \\
\hline$G_{\max }^{\mathrm{LS}}$ & 0.4 & 0.35 & 0.125 & 0.03 & 0.31 & 0.08 \\
\hline$k^{\frac{Z_{L}}{Z_{L}}}$ & 0.06 & 0.05 & 0.167 & 0.33 & 0.10 & 0.21 \\
\hline$k^{Z_{\mathrm{s}}}$ & 0.02 & 0.025 & 0.25 & 0.02 & 0.04 & 0.01 \\
\hline$k^{B}$ & 0.03 & 0.02 & 0.333 & 0.23 & 0.48 & 0.02 \\
\hline$k^{\mathrm{LS}}$ & 0.07 & 0.06 & 0.143 & 0.03 & 0.29 & 0.08 \\
\hline$\varepsilon^{Z_{\mathrm{L}}}$ & 0.35 & 0.3 & 0.143 & 0.03 & 0.06 & 0.03 \\
\hline$\varepsilon^{Z_{\mathrm{S}}}$ & 0.3 & 0.35 & 0.167 & 0.03 & 0.04 & 0 \\
\hline$\varepsilon^{B}$ & 0.3 & 0.35 & 0.167 & 0.25 & 0.35 & 0 \\
\hline$\varepsilon^{\mathrm{LS}}$ & 0.6 & 0.5 & 0.167 & 0.15 & 0.13 & 0.08 \\
\hline$\alpha^{P_{\mathrm{L}}}$ & 0.003 & 0.0025 & 0.167 & 0.11 & 0.08 & 0.10 \\
\hline$\alpha^{P \mathrm{~S}}$ & 0.02 & 0.015 & 0.25 & 0.04 & 0.12 & 0.08 \\
\hline$\alpha^{Z_{L}}$ & 0.02 & 0.025 & 0.25 & 0.18 & 0.13 & 0.09 \\
\hline$\alpha^{Z_{\mathrm{s}}}$ & 0.03 & 0.035 & 0.167 & 0.41 & 0.01 & 0.14 \\
\hline$\alpha^{B}$ & 0.5 & 0.6 & 0.2 & 0.39 & 0.58 & 0.10 \\
\hline$\delta_{P_{\mathrm{S}}}$ & 0.2 & 0.3 & 0.5 & 0.05 & 0.19 & 0.04 \\
\hline$\delta_{P_{\mathrm{L}}}$ & 0.6 & 0.7 & 0.167 & 0.16 & 0.05 & 0.15 \\
\hline$\delta_{\mathrm{D}}$ & 0.6 & 0.7 & 0.167 & 0.13 & 0.40 & 0.09 \\
\hline
\end{tabular}

large phytoplankton since the model-predicted values were sensitive to the maximum growth rate and half-saturation constant in the uptake of nutrients by large phytoplankton. A similar analysis was also made for the secondary production, which showed three sensitive bio-parameters: $V_{\max }^{\mathrm{DOP}}, k_{\mathrm{DOP}}$ and $\alpha^{B}$. These results indicated that in our 1-D model, the variation of secondary production was dominantly controlled by the maximum growth rate of bacteria by taking DOP in the detritus pool and its half-saturation constant via bacteria mortality rate. Since the flux to microzooplankton was one order of magnitude larger from bacteria than from small phytoplankton when a standard set of bio-parameters were used and also mean biomass was not affected significantly with these bio-parameters, the importance of microbial food web in the ecosystem of southern Michigan Lake was qualitatively meaningful.

In summary, we conclude that the seasonal variation pattern of phytoplankton and nutrients predicted by our 1-D model is robust. The more accurate estimation for the maximum growth rate and half-saturation constant for diatoms and maximum DOP uptake rate, half-saturation constant for the DOP uptake and mortality rate for bacteria must be made in order to provide more accurate simulation of primary and secondary productions. 


\section{References}

Beletsky, D., Schwab, D.J., 1998. Modeling thermal structure and circulation in Lake Michigan. Proceedings of the Estuarine and Coastal Modeling Fifth International Conference, October 22-24, 1997, Alexandria, VA, 511-522.

Beletsky, D., Schwab, D.J., McCormick, M.J., Miller, G.S., Saylor, J.H., Roebber, P.J., 2000. Hydrodynamic modeling for the 1998 Lake Michigan coastal turbidity plume event. Proceedings of the Estuarine and Coastal Modeling Conference, American Society of Civil Engineers, November 3-5, 1999, New Orleans, LA, 597-613.

Bentzen, E., Taylor, W.D., Millard, E.S., 1992. The importance of dissolved organic phosphorus to phosphorus uptake by limnetic plankton. Limnol. Oceanogr. 37, 217-231.

Biddanda, B., Ogdahl, M., Cotner, J.B., 2001. Variable contribution of heterotrophic bacteria to planktonic biomass and respiration in natural waters: relationship to system productivity. Limnol. Oceanogr. (In press).

Bieman, V.J., Dolan, D.M., 1981. Modeling of phytoplankton-nutrient dynamics in Saginaw bay, Lake Huron. J. Great Lake Res. 7 (4), 409-439.

Blumberg, A.F., Mellor, G.L., 1987. A description of a threedimensional coastal ocean circulation model. Coast. Estuar. Sci. 4, 1-6 In: Heaps, N.S. (Ed.), Three-Dimensional Coastal Ocean Model.

Brooks, A.S., Edington, D.N., 1994. Biogeochemical control of phosphate cycling and primary production in Lake Michigan. Limnol. Oceanogr. 39 (4), 961-968.

Cahill, R.A., 1981. Geochemistry of recent Lake Michigan sediments. III. Geol. Survey, Champaign, IL, Circ. 517, $94 p$.

Carrick, H.J., Fahnenstiel, G.L., 1990. Planktonic protozoan in Lake Huron and Michigan: seasonal abundance and composition of ciliates and dinoflagellates. J. Great Lake Res. 16, 319-329.

Carrick, H.J., Fahnenstiel, G.L., Stoermer, F.E., Wetzel, R.G., 1991. The importance of zooplankton-protozoan trophic couplings in Lake Michigan. Limnol. Oceanogr. $36,1335-1345$.

Chen, C., Wiesenburg, L.D.A., Xie, L., 1997. Influences of river discharge on biological production in the inner shelf: a coupled biological and physical model of the LouisianaTexas shelf. J. Mar. Res. 55, 293-320.

Chen, C., Ji, R., Zheng, L., Zhu, M., Rawson, M., 1999. Influences of physical processes on the ecosystem in Jiaozhou Bay: a coupled physical and biological model experiment. J. Geophys. Res. 104, 925-929.

Chen, C., Zhu, J., Ralph, E., Green, S.A., Budd, J.W., 2001. Prognostic modeling studies of the Keweenaw current in Lake Superior. Part I: formation and evolution. J. Phys. Oceanogr. 31, 379-395.

Conley, D.J., Quigley, M.A., Schelske, C.L., 1988. Silica and phosphorus flux from sediments: importance of internal recycling in Lake Michigan. Can. J. Fish. Aquat. Sci. 45, $1030-1035$.
Cotner, J.B., Wetzel, R.G., 1992. Uptake of dissolved inorganic and organic phosphorus compounds by phytoplankton and bacterioplankton. Limnol. Oceanogr. 37, 232-243.

Cotner, J.B., Johengen, T.H., Biddanda, B.A., 2000. Intense winter heterotrophic production stimulated by benthic resuspension. Limnol. Oceanogr. 45, 1672-1676.

Eadie, B.J., Chambers, R.L., Gardner, W.S., Bell, G.W., 1984. Sediment trap studies in Lake Michigan: resuspension and chemical fluxes in the southern basis. J. Great Lake Res. 10, 307-321.

Fahnenstiel, G.L., Scavia, D., 1987a. Dynamics of Lake Michigan phytoplankton: primary production and growth. Can. J. Fish. Aquat. Sci. 44, 499-508.

Fahnenstiel, G.L., Scavia, D., 1987b. Dynamics of Lake Michigan phytoplankton: recent changes in surface and deep communities. Can. J. Fish. Aquat. Sci. 44, 509-514.

Fahnenstiel, G.L., Krause, A.E., McCormick, M.J., Carrick, H.J., Schelske, C.L., 1998. The structure of the planktonic food-web in the St. Lawrence Great Lakes. J. Great Lake Res. 24 (3), 531-554.

Fasham, M.J.R., Duklow, H.W., Mckelvie, S.M., 1990. A nitrogen-based model of plankton dynamics in the oceanic mixed layer. J. Mar. Res. 48, 591-639.

Franks, P.J.S., Chen, C., 1996. Plankton production in tidal fronts: a model of Georges Bank in summer. J. Mar. Res. 54, 631-651.

Galperin, B., Kantha, L.H., Hassid, S., Rosati, A., 1988. A quasi-equilibrium turbulent energy model for geophysical flows. J. Atmos. Sci. 45, 55-62.

Gardner, W.S., Chandler, J.F., Laird, G.A., Scavia, D., 1986. Microbial response to amino acid additions in Lake Michigan: grazer control and substrate limitation of bacterial populations. J. Great Lakes Res. 12 (3), 161-174.

Gliwicz, Z.M., 1980. Filtering rates, food size selection and feeding rates in cladocerans: another aspect of interspecific competition in filter-feeding zooplankton. Am. Soc. Limnol. Oceanogr. Spec. Symp. 3, 282-291.

Hamilton, R.D., Preslon, J.E., 1970. Observations on the continuous culture of a planktonic phagotrophic protozoan. J. Exp. Mar. Biol. 5, 94-104.

Ji, R., Chen, C., Schwab, D.J., Beletsky, B., Fahnenstiel, G.L., Johengen, T.H., Vanderploeg, H., Eadie, B., Bundy, M., Gardner, W., Cotner, J., 2002. Influences of suspended sediments on the ecosystem in Lake Michigan: a 3-D coupled bio-physical modeling experiment. Ecol. Model. 152(2-3), 169-190.

Johengen, T.H., Johannsson, O.E., Pernie, G.L., Millard, E.S., 1994. Temporal and seasonal trends in nutrient dynamics and biomass measures in Lake Michigan and Ontario in response to phosphorus control. Can. J. Fish. Aquat. Sci. 51, 2570-2578.

Jorgensen, S.E., Nielsen, S.N., Jorge, L.A., 1991. Handbook of Ecological Parameters and Ecotoxicology. Elsevier, Amsterdam.

Liu, P.C., Schwab, D.J., 1987. A comparison of methods for estimating $\mathrm{U}^{*}$ from given $\mathrm{Uz}$ and air-sea temperature differences. J. Geophys. Res. 92 (C6), 6488-6494. 
McCormick, M.J., Tarapchak, S.J., 1984. Uncertainty analysis of calculated nutrient regeneration rates in Lake Michigan. Can. J. Fish. Aquat. Sci. 41, 206-211.

Mellor, G.L., Yamada, T., 1982. Development of a turbulent closure model for geophysical fluid problem. Rev. Geophys. Space Phys. 20, 851-875.

Melsom, A., 1996. Realistic near-surface momentum mixing in the Princeton Ocean Model. The Norwegian Meteorological Institute Research Report, No. 41, 25pp.

Moll, R., Brache, M., 1986. Seasonal and spatial distribution of bacteria, chlorophyll, and nutrients in nearshore Lake Michigan. J. Great Lake Res. 12 (1), 52-62.

Neilson, M., L'Italien, S., Glumac, V., Williams, D., Bertram, P., 1994. Nutrients: trends and ecosystem response. Report from the State of the Lakes Ecosystem Conference. Environment Canada, Ottawa, Ont.

Parsons, T.R., Takahashi, M., Hargrave, B., 1984. Biological Oceanographic Processes, third ed. Pergamon Press, New York.

Salencon, M.J., Thebault, J.M., 1996. Simulation model of a mesotrophic reservoir (Lac de Pareloup, France): MELODIA, an ecosystem reservoir management model. Ecol. Model. 84, 163-187.

Scavia, D., 1979. Examination of phosphorus cycling and control of phytoplankton dynamics in Lake Ontario with an ecological model. J. Fish. Res. Board Can. 36, 13361346.

Scavia, D., 1980. An ecological model of Lake Ontario. Ecol. Model. 8, 49-78.

Scavia, D., Fahnenstiel, G.L., 1987. Dynamics of Lake Michigan phytoplankton: mechanisms controlling epilimnetic communities. J. Great Lake Res. 13 (2), 103-120.

Scavia, D., Fahnenstiel, G.L., Evans, M.S., Jude, D.L., Lehman, J.T., 1986. Influence of salmonine predation and weather on long-term water quality trends in Lake Michigan. Can. J. Fish. Aquat. Sci. 43, 435-443.
Scavia, D., Lang, G.A., Kitchell, J.F., 1988. Dynamics of Lake Michigan plankton: a model evaluation of nutrient loading, competition, and predation. Can. J. Fish. Aquat. Sci. 45, 165-177.

Schelske, C.L., Stoermer, E.F., Fahnenstiel, G.L., Halbach, M., 1986. Phosphorus enrichment, silica utilization, and biogeochemical silica depletion in the Great Lakes. Can. J. Fish. Aquat. Sci. 43, 407-415.

Schwab, D.J., Beletsky, D., Lou, J., 2000. The 1998 coastal turbidity plume in Lake Michigan. Estuar. Coast. Shelf Sci. 50, 49-58.

Sherr, B.F., Sherr, E.B., Hopkinson, C.S., 1988. Trophic interactions within pelagic microbial communities: indications of feedback regulation of carbon flow. Hydrobiologia 159, $19-26$.

Thebault, J.M., Salencon, M.J., 1993. Simulation model of a mesotrophic reservoir (Lac de Pareloup, France): biological model. Ecol. Model. 65, 1-30.

Tilman, D., Kilham, S.S., Kilham, P., 1982. Phytoplankton community ecology: the role of limiting nutrients. Annu. Rev. Ecol. Sys. 13, 349-372.

Valiela, I., 1995. Marine Ecological Processes. Springer-Verlag, New York 686pp.

Vanderploeg, H.A., 1981. Seasonal particle selection by Diaptomus sicilis in offshore Lake Michigan. Can. J. Fish. Aquat. Sci. 38, 504-517.

Vanderploeg, H.A., 1994. Zooplankton particle selection and feeding mechanism. In: Wotton, R.S. (Ed.), The Biology of Particles in Aquatic Systems. Lewis, New York.

Vanderploeg, H.A., Paffenhofer, G.A., Liebig, J.R., 1988. Diaptomus vs net phytoplankton: effects of algal size and morphology on selectivity of a behaviorally flexiblem, omnivorous copepod. Bull. Mar. Sci. 43 (3), 377-394.

Zhu, J., Chen, C., Ralph, E., Green, S.A., Budd, J.W., 2001. Prognostic modeling studies of the Keweenaw current in Lake Superior. Part II: simulation. J. Phys. Oceanogr. 31, 396-410. 